\title{
Oxidation pond for municipal wastewater treatment
}

\author{
Erick Butler $^{1}$ Yung-Tse Hung ${ }^{2}$ Mohammed Suleiman Al Ahmad ${ }^{2} \cdot$ \\ Ruth Yu-Li Yeh ${ }^{3}$ Robert Lian-Huey Liu ${ }^{3}$ Yen-Pei Fu ${ }^{4}$
}

Received: 3 June 2014/Accepted: 7 April 2015/Published online: 23 April 2015

(c) The Author(s) 2015. This article is published with open access at Springerlink.com

\begin{abstract}
This literature review examines process, design, and cost issues related to using oxidation ponds for wastewater treatment. Many of the topics have applications at either full scale or in isolation for laboratory analysis. Oxidation ponds have many advantages. The oxidation pond treatment process is natural, because it uses microorganisms such as bacteria and algae. This makes the method of treatment cost-effective in terms of its construction, maintenance, and energy requirements. Oxidation ponds are also productive, because it generates effluent that can be used for other applications. Finally, oxidation ponds can be considered a sustainable method for treatment of wastewater.
\end{abstract}

Keywords Oxidation pond - Waste stabilization pond · Tertiary treatment - Wastewater treatment - Sustainability treatment

\section{Introduction}

Oxidation ponds, also known as waste stabilization ponds, provide greater advantages over mechanically based units.

Erick Butler

erick.ben.butler@gmail.com

1 School of Engineering and Computer Science, West Texas A\&M University, Canyon, TX 79016, USA

2 Department of Civil and Environmental Engineering, Cleveland State University, Cleveland, $\mathrm{OH} 44115$, USA

4 Chemical Engineering Department, Ming Hsin University of Science and Technology, Hsin-chu 30401, Taiwan

3 Department of Materials Science and Engineering, National Dong Hwa University, Hualien, 97401, Taiwan
First, ponds can be described as self-sufficient treatment units, because the efficacy of treatment is contingent upon the maintenance of the overall microbial communities of bacteria, viruses, fungi, and protozoa (Hosetti and Frost 1995), and the proper balance of organics, light, dissolved oxygen, nutrients, algal presence (Amengual-Morro et al. 2012), and temperature. Because ponds are self-sufficient, there is a reduction of operator responsibilities to manage treatment, a reduction in labor costs, and an increase in the potential fiscal returns from the tangible products generated by the treatment unit (Hosetti and Frost 1998).

Second, ponds can be used for the purpose of 'polishing,' or providing additional treatment to what has been found within conventional treatment methods (Veeresh et al. 2010). Various authors have conducted studies using oxidation ponds and other treatment methods such as anaerobic digestion (Gumisiriza et al. 2009), upflow anaerobic sludge blanket (Mungraya and Kumar 2008), membranes (Craggs et al. 2004), and reverse osmosis (Lado and Ben-Hur 2010). Third, ponds simplify the treatment process by reducing the need for multiple treatment units. Finally, oxidation ponds are a treatment process that can be used in regions where treating wastewater using conventional treatment methods is very expensive. Indeed, oxidation ponds are commonly used in many regions around the world, specifically in places with year-round mild to warm climates. In many developing countries, effluent from waste stabilization ponds has been reused in aquaculture and irrigation applications. Melbourne, Australia, implements irrigation by using sewage as early as the late-1890s. Latin American countries began projects in the 1960s, while the United Nations Development Programme (UNDP) Resource Recovery Project and the Pan American Health Organization (PAHO) have collaborated in research considering ponds for growing fish (Shuval et al. 1986). 
Many European Mediterranean countries also use oxidation ponds to treat municipal wastewaters. Forty-four ponds have served European populations between 500 and 40,000. Specifically in France, $77 \%$ of the ponds have been employed to serve populations under 1000, although the largest population served was a combined 14,000 from the cities of Meze and Louipan, using a facultative pond and a maturation pond system. Ponds are also being used in countries such as Greece, Egypt, Algeria, Morocco, and Tunisia (Mara and Pearson 1998). The additional advantages and disadvantages are summarized in Table 1.

For these reasons, the oxidation pond provides an attractive method of sustainable wastewater treatment with the following caveats: operators should monitor the chemical and biological constituents within the system to ensure proper design parameters are met to correspond with regulatory treatment efficiency standards (Hosetti and Frost 1998), especially if the effluent is to be reused.

While the authors' research supports the use of oxidation ponds, it makes no claim concerning the closely related lagoon. Waste stabilization and oxidation ponds are synonymous, but oxidation ponds are different from lagoons. Lagoons are single or multi-celled designed natural wastewater treatment reservoirs that house diluted manure for the purpose of removing organics and other constituents by means of microorganisms or other biological processes. Similar to waste stabilization ponds, lagoons can operate under various conditions of dissolved oxygen depending on the type of microorganisms that are present. However, lagoons are more commonly affiliated with agricultural

Table 1 Advantages and disadvantages of waste stabilization ponds (Mara et al. 1992)

\begin{tabular}{ll}
\hline Advantages & Disadvantages \\
\hline Easy to construct & $\begin{array}{c}\text { Requires a large land area } \\
\text { High BOD and TSS with } \\
\text { algae concentrations }\end{array}$ \\
Low cost & \\
Effluent does not require disinfection & \\
Capable of handing a variety of & \\
hydraulic loads & \\
Ideal for small communities and also \\
tropical region \\
Completes sludge treatment \\
Handles varying wastewater types \\
(industrial or municipal) \\
BOD, fecal coliform, and helminth \\
removal is higher than by other \\
treatment methods \\
such as activated sludge, biological \\
filters, and rotational biological \\
contactors
\end{tabular}

$B O D$ Biochemical oxygen demand, TSS total suspended solids wastewater (Hamilton et al. 2006) and should not be confused with oxidation ponds.

The purpose of this text is to review the significance of oxidation ponds within wastewater treatment by discussing the types, design considerations, and treatments that have been completed by this particular method.

\section{Types of oxidation ponds}

There are four major types of oxidation ponds: aerobic (high-rate), anaerobic, facultative, and maturation ponds.

\section{Aerobic (high-rate) ponds}

Aerobic ponds, also known as high-rate algal ponds, can maintain dissolved oxygen throughout the 30-45 cm-deep pond because of algal photosynthetic activity (USEPA 2011). Photosynthetic activity supplies oxygen during the day, while at night the wind creates aeration due to the shallow depth of the pond (Davis and Cornwell 2008). Aerobic ponds are well known for having high biochemical oxygen demand (BOD) removal potential and are ideal for areas where the cost of land is not expensive. Other characteristics of these ponds include a detention time of 2-6 days, a BOD loading rate between 112 and $225 \mathrm{~kg} /$ $1000 \mathrm{~m}^{3}$ day, and a BOD removal efficiency of $95 \%$ (USEPA 2011).

\section{Anaerobic ponds}

Anaerobic ponds operate without the presence of dissolved oxygen. Under methanogenic conditions, the major products are carbon dioxide and methane (Quiroga 2011). Typically, these ponds are designed to have a depth of 2-5 m, with a detention time between 1 and 1.5 days, an optimum $\mathrm{pH}$ less than 6.2 , temperatures greater than $15^{\circ} \mathrm{C}$ (Kayombo et al. 2010), and an organic loading rate of $3000 \mathrm{~kg} \mathrm{ha/day} \mathrm{(Quiroga} \mathrm{2011;} \mathrm{Kayombo} \mathrm{et} \mathrm{al.} \mathrm{2010).}$ Anaerobic ponds can remove $60 \%$ BOD. However, this efficiency is climate dependent (USEPA 2011). The driving force behind treatment is sedimentation. Helminths settle to the bottom of the pond, and bacteria and viruses are removed by attaching to settling solids within the pond or die with the loss of available food or by the presence of predators. In practice, anaerobic ponds are usually incorporated alongside facultative ponds (Martinez et al. 2014).

\section{Facultative ponds}

A facultative pond is a treatment unit with anaerobic and aerobic conditions. A typical pond is divided into an aerobic surface region consisting of bacteria and algae, an 
anaerobic bottom region, consisting of anaerobic bacteria, and a region in between anaerobic and aerobic conditions where bacteria can thrive in both conditions (Kayombo et al. 2010; Joint Departments of the Army, the Navy, and the Air Force 1988). If used in series, effluent from a previously treated source enters the pond (Quiroga 2011; Kayombo et al. 2010). Facultative ponds treat BOD, typically within a range of $100-400 \mathrm{~kg} \mathrm{BOD} / \mathrm{ha} / \mathrm{day}$, by removing BOD by $95 \%$. Because facultative ponds employ algae as decomposers, the treatment time can range between 2 and 3 weeks, which is attributed to the photosynthetic processes that occur within the unit. A facultative pond on average has a depth of 1-2 m (Kayombo et al. 2010).

\section{Maturation ponds}

Similar to facultative ponds, maturation ponds use algae as a primary driving force in the treatment. Nevertheless, while facultative ponds typically treat BOD, maturation ponds remove fecal coliform, pathogens, and nutrients (Cinara 2004). In comparison with the other pond types, the characteristics of the maturation pond include a depth range between 1 and $1.15 \mathrm{~m}$ (Kayombo et al. 2010), which makes it shallower than all of the ponds besides the aerobic. Generally, maturation ponds maintain anaerobic conditions (Martinez et al. 2014).

\section{Arrangement of ponds}

Treatment by waste stabilization ponds occurs by using a single pond to handle treatment or by a multiple pond system. Figures 1, 2, 3, 4, and 5 depict a multiple pond system in Wellington, Texas, a small town in the Texas Panhandle. The system treats the town's wastewater which is used for irrigation (Fig. 6). There are two arrangements for a multiple pond system-series and parallel. In the series arrangement, wastewater is treated in the initial and subsequent ponds and then polished in the final pond. On the contrary, wastewater flow is evenly divided in the parallel pond arrangement. The USEPA states that wastewater flow division normally occurs in the first two waste stabilization ponds (USEPA 2011).

Each multiple pond arrangement has its benefits and therefore an operator can change the pond arrangement depending on the situation. For example, ponds operating in parallel prevent interruption of treatment during the cooler months of the year. This is when a pond can experience low biological activity. Low biological activity can create anaerobic conditions within a pond. In addition, the application of ponds in parallel can reduce problems related to periodic low dissolved oxygen concentrations, particularly in the morning hours (USEPA 2011). Also, Mara and Pearson (1998) recommend this arrangement when the population of the city reaches 10,000 . On the

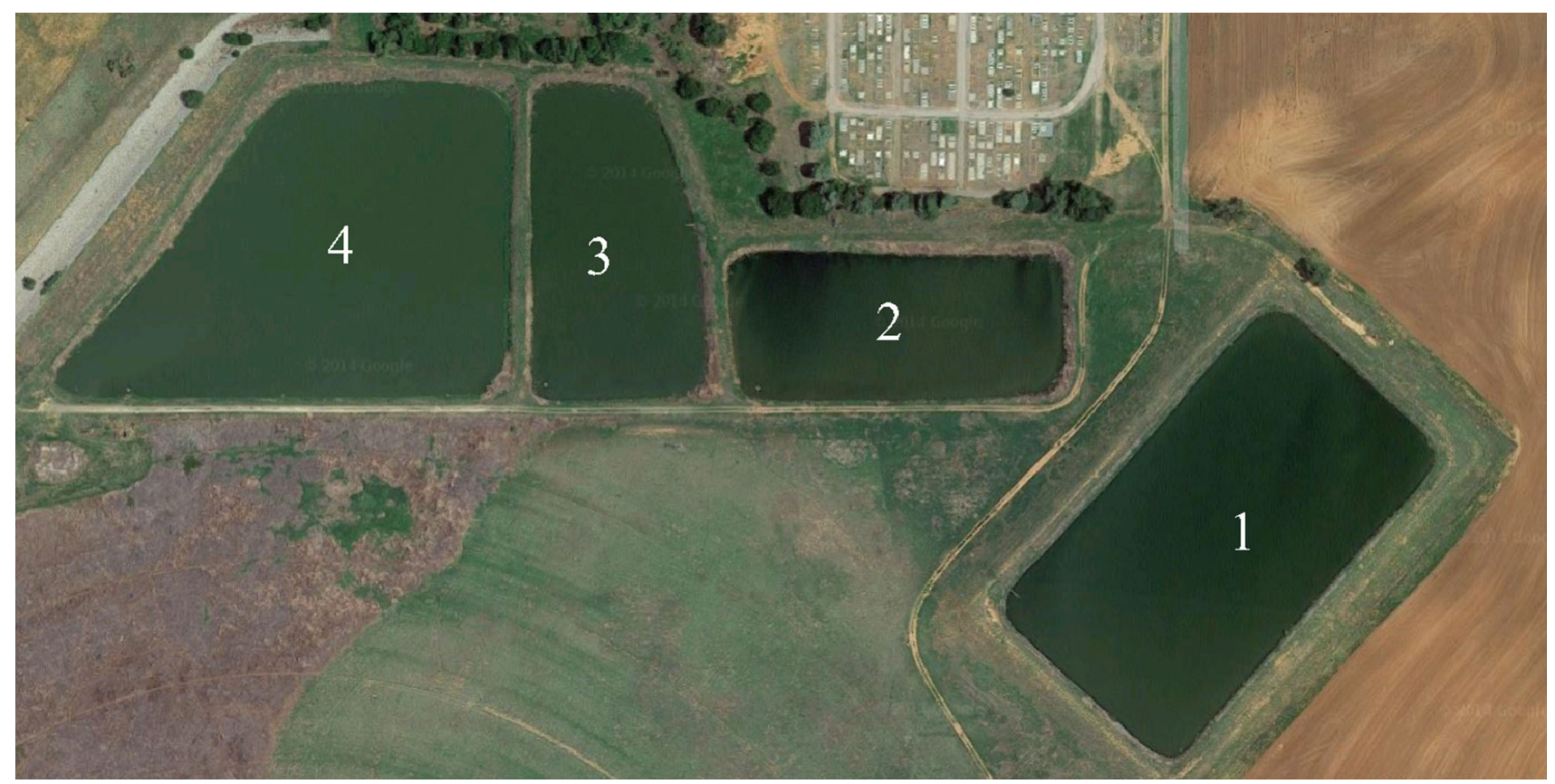

Fig. 1 A multiple pond treatment system in Wellington, TX, USA. The pond system consists of a facultative lagoon (1) and three oxidation ponds (2-4) (Google Map 2014) 


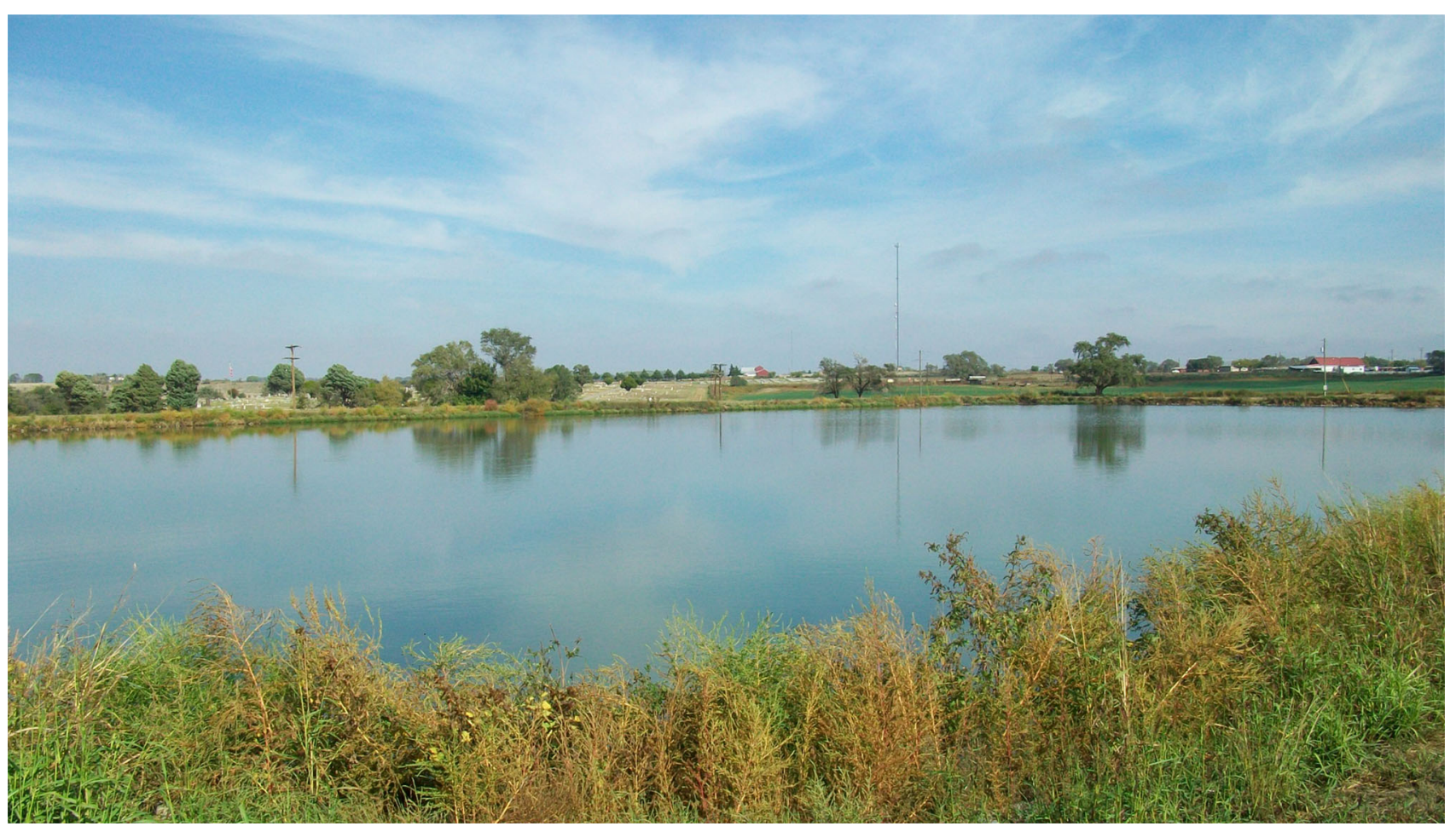

Fig. 2 Facultative lagoon in the treatment system in Wellington, TX, USA. Photograph taken by the author

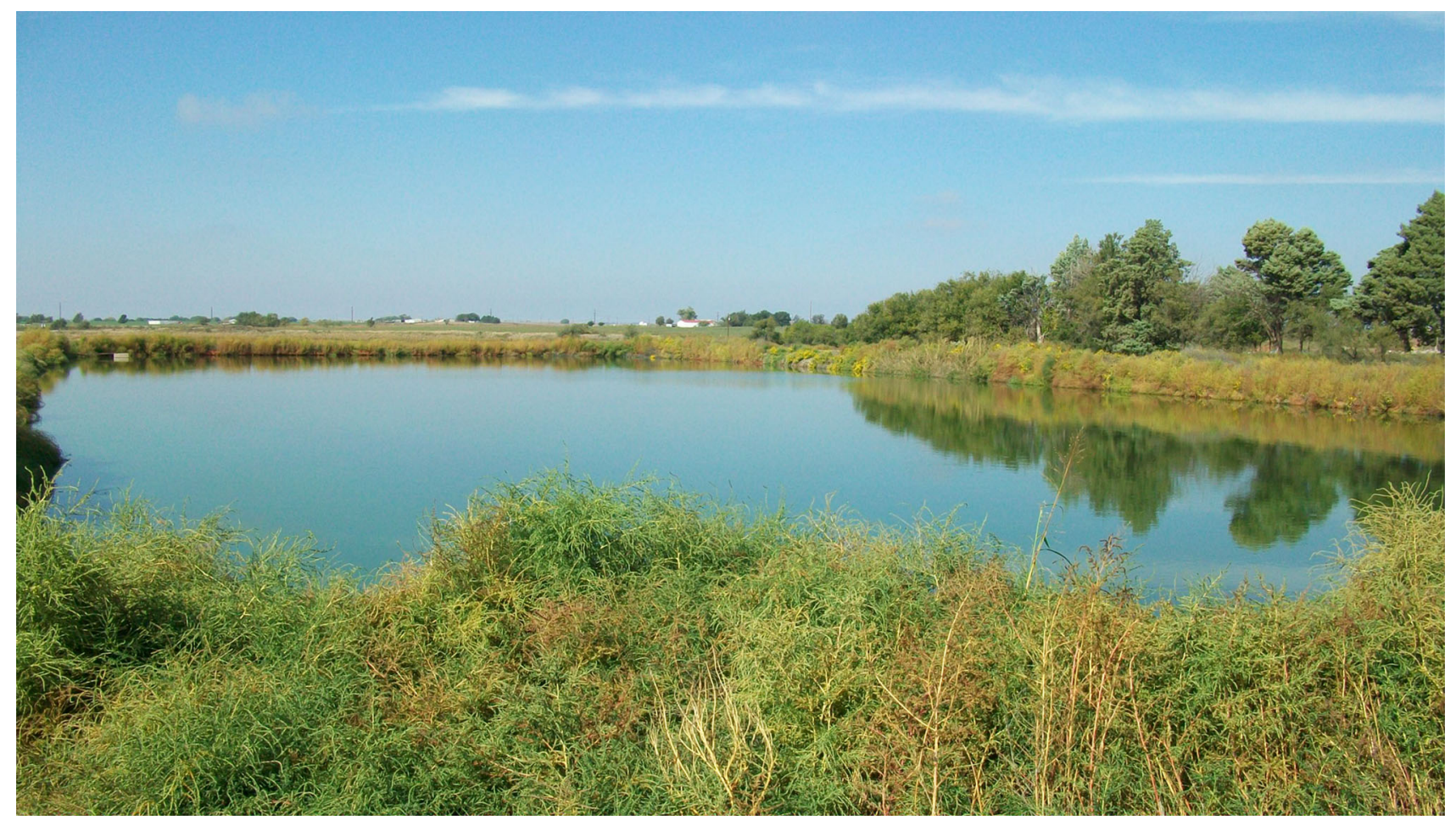

Fig. 3 Oxidation pond 1 in the treatment system in Wellington, TX, USA. Photograph taken by the author 


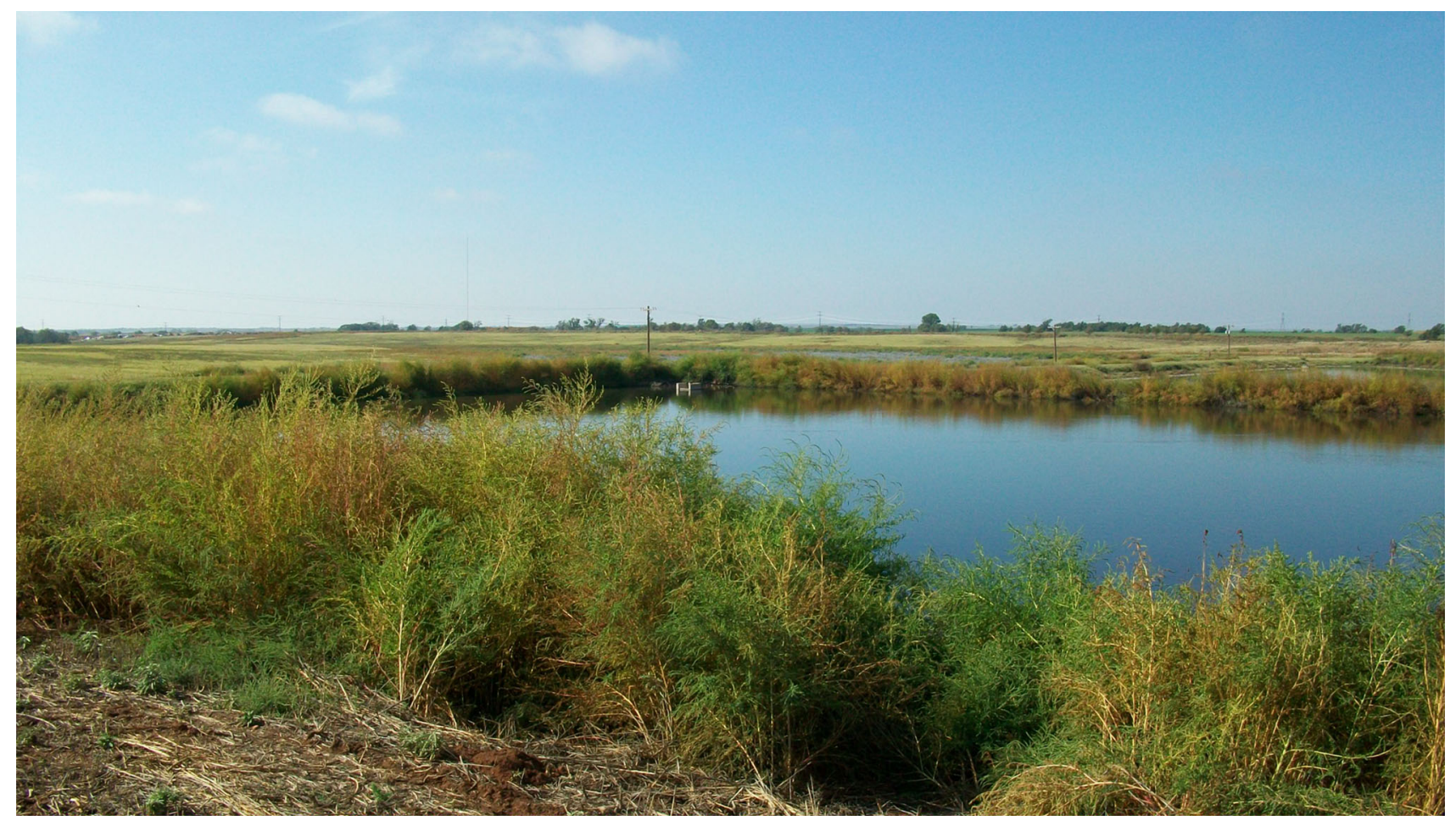

Fig. 4 Oxidation pond 2 in the treatment system in Wellington, TX, USA. Photograph taken by the author

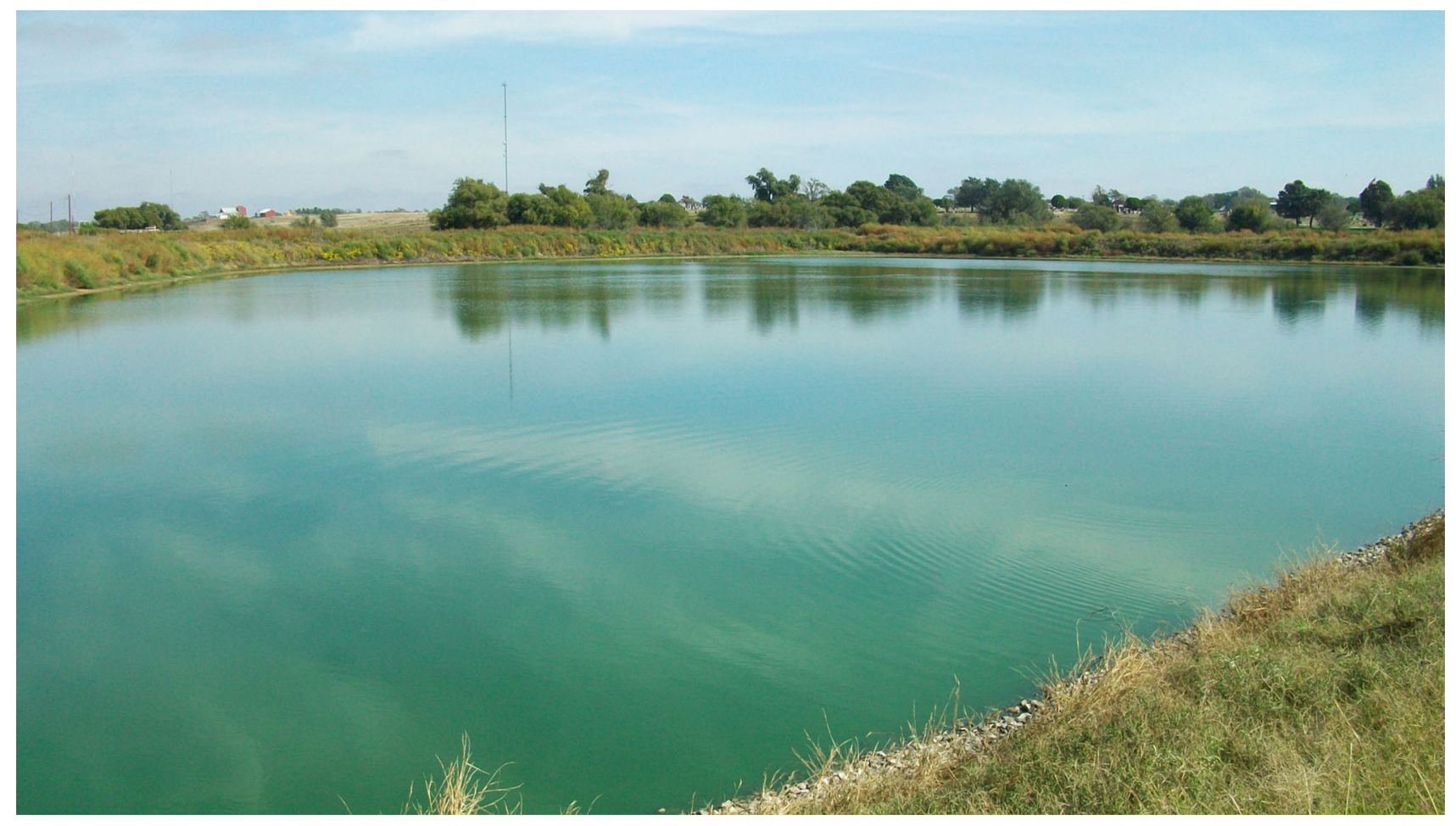

Fig. 5 Oxidation pond 3 in the treatment system in Wellington, TX, USA. Photograph taken by the author 


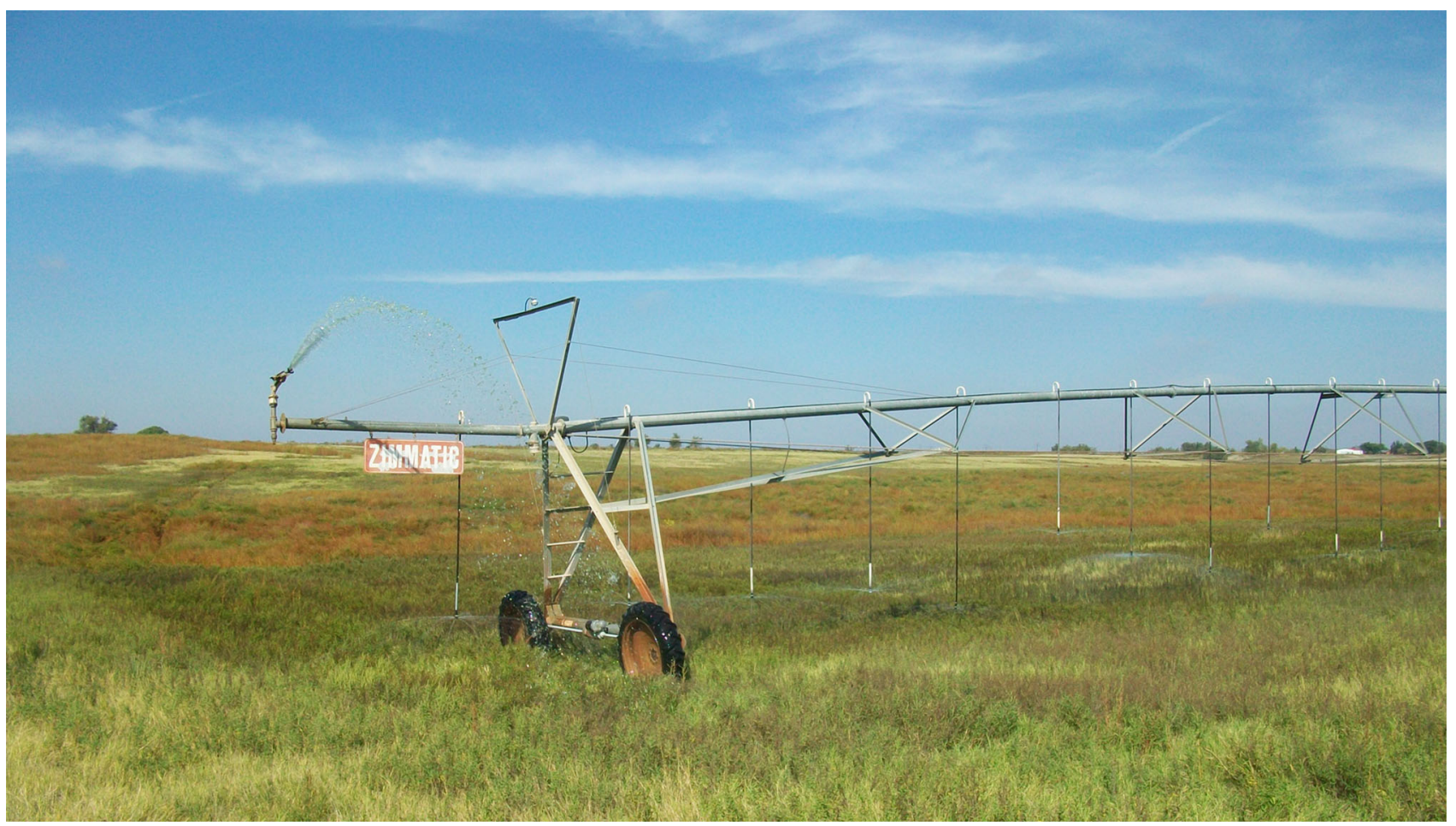

Fig. 6 Central pivot irrigation system directly applies effluent from the pond system in Wellington, TX, USA. Photograph taken by the author

other hand, ponds in series are ideal during the summer months and also during periods of low biological loading (USEPA 2011). Nevertheless, the choice of applying multiple ponds can be beneficial for treatment as compared to a single pond arrangement.

\section{Design of oxidation ponds}

Oxidation ponds are designed to function as either completely stirred or plug flow reactors, but mass transport mechanisms have a greater impact than the type of reactor model chosen. There are four major mass transport mechanisms acting in oxidation ponds-diffusion, advection, gravity, and interception. The mechanism(s) observed are contingent on the type of wastewater treated (Peña and Mara 2003).

There are many methods available for the design of waste stabilization ponds. For example, facultative pond design can use the areal loading rate, Gloyna equation, plug flow model, Marais and Shaw model, and the Thirumurthi application. The design equations for each procedure together with design limitations are shown below.

\section{Areal loading rate}

The areal loading rate design procedure optimizes an organic loading rate into a waste stabilization pond by examining various factors such as the volumetric loading, organic constituents within the wastewater, the ability of algae to use sunlight to grow and supply oxygen, and BOD loading per unit area (USEPA 1983). Climate impacts the BOD loading rate, as the loading rate is directly related to the ability of a pond to avoid becoming anaerobic (Gloyna 1971). The areal loading rate procedure limits $\mathrm{BOD}_{5}$ loading rates between 11 and $22 \mathrm{~kg} / \mathrm{ha} /$ day when the temperature is below $0{ }^{\circ} \mathrm{C}$ and a hydraulic detention time between 120 and 180 days (Gloyna 1971; USEPA 2011), as opposed to tropical climates which can handle higher $\mathrm{BOD}_{5}$ loading rates. Therefore, the use of areal loading rate is climate dependent and may not be as predictable as other methods.

\section{Gloyna equation}

Authors Hermann and Gloyna attempted to address the limitations of the areal rate procedure with a method of determining the volume of a waste stabilization pond that would maintain a high BOD removal (80-90\%) despite the change in temperatures (Marais 1966). The authors state that if the average coldest water temperature of the year is known along with a loading factor based on the product of the total population and waste per capita, the volume of the pond can be determined graphically. The procedure is as follows. The design engineer begins by 
computing the loading factor. Because the graph consists of lines representing water temperatures, the engineer would find the computed loading factor on the abscissa, move vertically toward the average coldest temperature line, and read the volume on the ordinate. After selecting the volume, the depth was found using a table of recommended depths (Gloyna 1971).

Gloyna further expanded on this to create an empirical equation that summarizes the relationship between pond volume, BOD concentration, and flow rate (Finney and Middlebrooks 1980):

$V=3.5 \times 10^{-5} Q L_{a}\left(\ominus^{(35-T)}\right) f f^{\prime}$,

where $V$ is the pond volume, $\mathrm{m}^{3} ; Q$ the influent flow rate, $1 /$ day; $L_{a}$ the ultimate BOD or COD, mg/L; $\theta$ the temperature coefficient; $T$ the pond temperature, Celsius; $f$ the algal toxicity factor (1.0 for domestic and industrial wastes); $f^{\prime}$ the sulfide oxygen demand (1.0 for $\mathrm{SO}_{4}$ concentration less than $500 \mathrm{mg} / \mathrm{L}$ ).

In addition, Gloyna attempted to adjust for sunlight by multiplying the computed volume from Eq. (1) and the quotient of solar radiation in the area and the solar radiation found in the southwest.

However, there are several limitations within the Gloyna equation. Finney and Middlebrooks argued that the use of Gloyna's equation cannot be applied to all ponds, because it does not always correctly predict pond depths or BOD removal efficiencies. The authors also mention that the sunlight correction can have more of an impact on the volume than the other variables in the equation (Finney and Middlebrooks 1980). In addition, Marais (1966) concluded that the sizing of ponds by Gloyna's equation results in the design of smaller ponds in series, rather than using one larger pond to meet the same treatment objective.

\section{Plug flow model}

The plug flow model, derived from first-order kinetics, considers not only the $\mathrm{BOD}_{5}$ concentration, but also the rate reaction rate $\left(k_{\mathrm{p}}\right)$. The $k_{\mathrm{p}}$ is chosen based on the $\mathrm{BOD}_{5}$ loading rate and the pond temperature. Table 2 provides the $k_{\mathrm{o}}$ based on $\mathrm{BOD}_{5}$ loading rate at $20{ }^{\circ} \mathrm{C}$ (USEAP

Table $2 \mathrm{BOD}_{5}$ loading rate based on $k_{\mathrm{p}}$ at $20{ }^{\circ} \mathrm{C}$ (USEPA 1983)

\begin{tabular}{ll}
\hline $\mathrm{BOD}_{5}$ loading rate $(\mathrm{kg} / \mathrm{ha} / \mathrm{d})$ & $k_{p_{20}}\left(\mathrm{~d}^{-1}\right)$ \\
\hline 22 & 0.045 \\
45 & 0.071 \\
67 & 0.083 \\
90 & 0.096 \\
112 & 0.129 \\
\hline
\end{tabular}

1983). The plug flow model is presented in Eq. (2) at a temperature of $20{ }^{\circ} \mathrm{C}$ (USEPA 1983):

$C_{\mathrm{e}} / C_{\mathrm{o}}=e^{-k_{\mathrm{p}} t}$

where $C_{\mathrm{e}}$ is the effluent $\mathrm{BOD}_{5}$ concentration, $\mathrm{mg} / \mathrm{L} ; C_{\mathrm{o}}$ the influent $\mathrm{BOD}_{5}$ concentration, $\mathrm{mg} / \mathrm{L} ; e$ the base of natural logarithm, $2.7183 ; k_{\mathrm{p}}$ the plug flow first-order reaction rate, day $^{-1} ; t$ the hydraulic resident time in each pond, days.

To use the plug flow model at other temperatures, a subsequent equation is required. Equation (3) converts the temperature from $20^{\circ}$ to the desired temperature (USEPA 1983):

$k_{\mathrm{p}_{T}}=k_{\mathrm{p}_{20}}(1.09)^{T-20}$,

where $k_{\mathrm{p}_{T}}$ is the reaction rate at minimum operating water temperature, day ${ }^{-1 ;} k_{p_{20}}$ the reaction rate at $20{ }^{\circ} \mathrm{C} ; T$ the minimum operating water temperature, ${ }^{\circ} \mathrm{C}$.

\section{Marais and Shaw}

Marais and Shaw developed a pond equation that combines both first-order kinetics and completely mixed conditions (Crites et al. 2006). This can also be used by designers for aerobic pond design (USEPA 2011; Crites et al. 2006):

$C_{\mathrm{n}} / C_{\mathrm{o}}=1 /\left(1+k_{\mathrm{c}} t_{\mathrm{n}}\right)^{n}$,

where $C_{\mathrm{n}}$ is the effluent $\mathrm{BOD}_{5}$ concentration, $\mathrm{mg} / \mathrm{L} ; C_{\mathrm{o}}$ the influent $\mathrm{BOD}_{5}$ concentration, $\mathrm{mg} / \mathrm{L} ; k_{\mathrm{c}}$ the complete-mix flow first-order reaction rate, day ${ }^{-1} ; t_{\mathrm{n}}$ the hydraulic resident time in each cell, days; $n$ the number of equal-sized pond cells in series.

The developed equation is based on the following assumptions (Marais 1966; Finney and Middlebrooks 1980):

1. Assume that the pond is completely mixed, with no changes in pond state.

2. Treat the pond effluent as equal to the influent under equilibrium conditions, with slight variations of pollutant concentration within the influent.

3. Pollution removal increases within a series of ponds until reaching a desired removal rate.

4. BOD does not settle as sludge (Finney and Middlebrooks 1980).

\section{Thirumurthi application}

Thirumurthi argued that Marais and Shaw's assumption of completely mixed conditions is not ideal for designing a waste stabilization pond, but suggests using a chemical reaction (Eq. 5) (Finney and Middlebrooks 1980; Thirumurthi 1974):

$C_{\mathrm{e}} / C_{\mathrm{i}}=4 a e^{1 / 2 d} /(1+a)^{2} e^{a / 2 d}-(1-a)^{2} e^{-a / 2 d}$, 
where $C_{\mathrm{e}}$ is the effluent biochemical oxygen demand (BOD), $\mathrm{mg} / \mathrm{L} ; C_{\mathrm{i}}$ is the influent BOD, $\mathrm{mg} / \mathrm{L} ; K$ is the firstorder BOD removal coefficient, day ${ }^{-1} ; t$ is the mean detention time, days; $a=\sqrt{ }(1+4 K t d) ; d=D t / L^{2} ; d$ is the dimensionless dispersion number; $D$ is the axial dispersion coefficient, $\mathrm{ft}^{2} / \mathrm{h}$.

The thesis of this application is to focus on the firstorder BOD removal coefficient $(K)$, making corrections due to temperature, organic load, toxic contaminants, and solar radiation (Thirumurthi 1974). Equation (6) summarizes the factors that are associated with $K$ (Finney and Middlebrooks 1980; Thirumurthi 1974):

$K=K_{8} C_{\mathrm{Te}} C_{\mathrm{o}} C_{\mathrm{T} 0 x}$,

where $K$ is the first-order BOD removal coefficient, day ${ }^{-1}$; $K_{8}$ the $\mathrm{BOD}_{5}$ removal coefficient, day ${ }^{-1} ; C_{\mathrm{Te}}$ the correction factor for temperature; $C_{\mathrm{o}}$ the correction factor for organic load; $C_{\mathrm{T} 0 x}$ the correction factor for toxic chemicals.

\section{Anaerobic pond design}

Anaerobic pond design is contingent on the volumetric loading rate into the pond. This is based on the water temperature and hydraulic retention time. Table 3 provides treatment efficiency based on major operating parameters.

Overall, there are different methods that can be utilized to design a waste stabilization pond. Choosing the appropriate design technique requires careful consideration of assumptions and limitations, pond type, and the wastewater quality indicators that are desired to be analyzed and removed.

\section{Operation and design parameters}

\section{Operation parameters}

The major operation parameters for oxidation ponds include light penetration, temperature, wind, pond geometry, and oxygen concentration.

\section{Light penetration}

Light penetration affects the process of photosynthetic organisms utilizing sunlight to produce oxygen. Therefore, recognizing such factors as an organism's ability to absorb light at given wavelengths (optimal wavelength range for photosynthesis is between 400 and $700 \mathrm{~nm}$ ), also known as photosynthetic active radiation (PAR) (Curtis et al. 1994), the presence of suspended material, and the climate and geographic location of the pond (USEPA 2011) will assist in providing a framework for evaluation during operation. In addition, the natural scattering of light particles due to water characteristics and the presence of microorganisms can further impact the usefulness of light that enters into the pond (Curtis et al. 1994).

\section{Temperature}

Since this is a natural treatment system, it is also important to understand that the temperature cannot be regulated. Rather, temperature analysis plays a significant role in understanding the efficiency of the oxidation pond as a treatment system, the control of nitrification (Kirby et al. 2009), methane production during anaerobic digestion

Table 3 Operating parameters for anaerobic ponds (USEPA 2011)

\begin{tabular}{|c|c|c|c|c|c|c|c|c|}
\hline \multicolumn{2}{|c|}{$\operatorname{ALR} \mathrm{BOD}_{5}(\mathrm{~kg} / \mathrm{ha} / \mathrm{d})$} & \multicolumn{2}{|c|}{ Est. VLR $\left(\mathrm{kg} / 1000 \mathrm{~m}^{3}\right)$} & \multicolumn{2}{|c|}{ Removal (\%) } & \multirow[t]{2}{*}{ Depth (m) } & \multirow[t]{2}{*}{ HRT (day) } & \multirow[t]{2}{*}{ References } \\
\hline Summer & Winter & Summer & Winter & Summer & Winter & & & \\
\hline 66.2 & & 37.6 & & 75 & & $0.9-1.2$ & & Parker (1970) \\
\hline 51.5 & & 29.5 & & 65 & & $0.9-1.2$ & & Parker (1970) \\
\hline 18.4 & & 10.6 & & 86 & & $0.9-1.2$ & & Parker (1970) \\
\hline 31.3 & & 17.8 & & 52 & & $0.9-1.2$ & & (Parker 1970) \\
\hline 103.0 & 73.6 & 58.9 & 42.1 & 89 & 60 & $0.9-1.2$ & & (Parker 1970) \\
\hline 73.6 & 18.4 & & & 70 & & & & Oswald (1968) \\
\hline \multirow[t]{2}{*}{$165.6-220.8$} & 124.2 & $83.0-110.6$ & 62.3 & $60-70$ & & $0.9-1.5$ & $2-5$ & Parker et al. (1959) \\
\hline & & & & & & $2.4-3.1$ & $30-50$ & Eckenfelder et al. (1961) \\
\hline $36.8-110.4$ & & & $8.2-22.2$ & & & & $15-160$ & Cooper (1968) \\
\hline \multirow[t]{2}{*}{92.0} & & & 18.5 & 70 & & $2.4-3.1$ & 5 & Oswald et al. (1967) \\
\hline & & & & & & $2.4-3.7$ & $2(\mathrm{~s}) 5(\mathrm{w})$ & Malina and Rios (1976) \\
\hline
\end{tabular}

$A L R B O D_{5}$ areal loading rate $\mathrm{BOD}_{5}(\mathrm{~kg} / \mathrm{ha} / \mathrm{d})$, Est. $V L R$ estimated volumetric loading rate $\left(\mathrm{kg} / 1000 \mathrm{~m}^{3}\right), H R T$ hydraulic retention time (day). This has been converted from English to SI units 
(Sukias and Craggs 2011), COD removal (Daviescolley et al. 1995), the handling of heavy metals (Mona et al. 2011), bacteria growth (Halpern et al. 2009; Olaniran et al. 2001), and the influence of bacteria and algal presence on pond productivity (Quiroga 2011).

One of the major ways that temperature impacts pond productivity is during the summer and winter months, when the surface water heated by the sunlight remains at the top of the pond and cooler denser water is at the bottom. The noticeable change in temperature with increasing depth creates layers or 'strata', a phenomenon known as stratification. Stratification is intensified in the winter months when sheets of ice can form within the pond layers, reducing light penetration and further water layer formation (USEPA 2011). Access to sunlight is limited during both seasons producing anaerobic conditions (Marais 1966). Stratification limits the metabolism of algae and aerobic bacteria in the pond.

Conversely, during the spring months, temperature differences are lessened, and surface water and water at lower depths will combine by mixing (USEPA 2011). Mixing also causes turnover of sediments from the bottom of the pond increasing the available suspended solids concentration to be removed by microorganisms (Finney and Middlebrooks 1980). Seasonal changes impact the water depth through rainfall and evaporation (Hamilton et al. 2006).

\section{Wind}

Wind is important in preventing anaerobic conditions by mixing warmer and cooler layers of water (USEPA 2011; Marais 1966). This reduces the potential for stratification, odors, and short-circuiting (USEPA 2011). However, the effectiveness of wind energy is contingent on the temperature of the pond, as the required energy to reduce $1^{\circ}$ of pond temperature increases with increasing temperature of the pond (Marais 1966).

Wind patterns and wind speed control the overall removal of bacteria. Various studies compare wind speeds, direction, and also the implementation of baffles within the simulated waste stabilization ponds. The factors related to bacteria removal include the direction, speed of wind, and the presence of baffles, particularly L-shaped baffles, where winds blowing parallel to the inlet-outlet of the pond produce poorer results as compared to the orthogonal orientation of the pond. Nevertheless, the results may vary with increasing wind speeds (Badrot-Nico et al. 2010). Wind coupled with pond geometry can likewise have an impact on treatment performance. For example, in the aerobic layer of facultative ponds the presence of wind leads to vertical mixing and the distribution of dissolved oxygen, bacteria, algae, and BOD. This creates a quality effluent. However, without the wind, algae create a $20 \mathrm{~cm}$ - thick layer moving through $50 \mathrm{~cm}$ of the pond. This leads to a variable quality effluent (Mara and Pearson 1998).

\section{Pond geometry}

Having analyzed two different pond types with varying dimensions and depths, Pearson et al. (1995) confirmed that pond geometry alone does not indicate a strong relationship with treatment performance. Consequently, optimum treatment can be achieved at low dimension ratios, along with shallower pool depths. This can eliminate high construction costs. While the pond geometry may not have indicated an effect on a pond's performance, Hamdan and Mara's comparison between horizontal and vertical pond orientation for the treatment of total Kjeldahl nitrogen (TKN) showed that the vertical-flow orientation has a better treatment performance as compared to the horizontal flow (Hamdan and Mara 2011).

In addition, Abbas et al. (2006) concluded that the dimensions of the waste stabilization pond affect the removal of $\mathrm{BOD}_{5}$. Their model, initiated from the conservation of moment and mass equations solved by using NewtonRaphson non-linear iterations, find increasing $\mathrm{BOD}_{5}$ removal when the number of baffles was 2. High performance is found regardless of the dimensions at four baffles (peak performance recorded at a dimension ratio of 4 , $\mathrm{BOD}_{5}=95.8 \%$ ), while low performance is seen at no baffles (ranging from 16.1 to $21.6 \%$, from 1 to 4 dimension ratio). Therefore, pond geometry can monitor the efficiency of pollutant removal in a pond.

\section{Design factors}

Understanding design factors is important in controlling pollutants such as $\mathrm{BOD}_{5}$. There are many factors that affect the efficiency of $\mathrm{BOD}_{5}$ removal in waste stabilization ponds. These factors include raw wastewater strength, food-to-microorganism ratio, organic loading rates, $\mathrm{pH}$, and hydraulic detention time (HRT).

Hydraulic retention time is important because it determines not only how long the wastewater remains within the pond, but also the treatment efficiency. In general, the HRT was found to be as low in literature as $18 \mathrm{~h}$ (Gumisiriza et al. 2009) and as high as 300 days (Shpiner et al. 2007). Various authors propose different HRT values because of the type of wastewater treated and the type of pond treatment applied. For example, $18 \mathrm{~h}$ is sufficient to treat fishprocessing wastewater by combining the oxidation pond with anaerobic digestion (Gumisiriza et al. 2009), while Quiroga (2011) recommends that the retention time for the design of an anaerobic pond in Canada range between 2 and 5 days. 
The significance of the $\mathrm{pH}$ range becomes important when taking into account the presence of microorganisms and other biological species that are needed for the purpose of enhancing treatment. The $\mathrm{pH}$ has been regulated for optimum growth of algal species (Bhatnagar et al. 2010), sulfate-reducing bacteria (Burns et al. 2012), macrophytes (Kirby et al. 2009), and Salvinia rotundifolia (Banerjee and Sarker 1997). For example, photosynthesis by algae increases $\mathrm{pH}$ through the presence of hydroxide ions that are formed by the use of carbon dioxide (USEPA 2011). Various authors set the $\mathrm{pH}$ range as low as 3-5 (Burns et al. 2012), while the highest $\mathrm{pH}$ range is 4-11 (Bhatnagar et al. 2010).

While this text studies the aforementioned as the most frequent parameters, other parameters may have an effect on an oxidation pond's performance, such as flow rate (Kirby et al. 2009; Faleschini et al. 2012), volume (Fyfe et al. 2007), and area (Craggs et al. 2003). However, there are still other parameters that can be considered, but the previously mentioned have been surveyed as having the most effect on the overall treatment of wastewater within oxidation ponds.

\section{Wastewater characteristics}

The characteristics of wastewater are very important when determining the most efficient treatment system. Oxidation ponds treat various wastewaters consisting of nitrogen and phosphorus, heavy metals, organics, and pharmaceuticals. The following includes the mechanisms involved in treating for these specific constituents, along with results that have been outlined in the literature.

\section{Nutrients}

In the case of nitrogen, volatilization, specifically ammonia volatilization, is the most common method applied (USEPA 2011; Kayombo et al. 2010). Other methods for reducing nitrogen include deposition, adsorption, nitrification, and denitrification (USEPA 2011). On the other hand, phosphorus treatment uses various processes such as precipitation, sedimentation, and uptake by algal biomass (Kayombo et al. 2010). Nevertheless, oxidation ponds have been effective in removing nutrients.

Nutrient removal is contingent upon the type of oxidation pond (Kayombo et al. 2010). For example, Ke et al. (2012) combined submerged macrophyte oxidation ponds (SMOPs) and subsurface vertical-flow (SVFW) ponds to treat particulate phosphorus (PP) and total dissolved phosphorus (TDP). Garcia et al. (2002) combine two highrate oxidation ponds (HROPs) for phosphorus removal.
Table 4 Treatment efficiencies of nutrients in oxidation ponds

\begin{tabular}{llll}
\hline Nutrient & $\begin{array}{l}\text { Efficiency } \\
(\%)\end{array}$ & $\begin{array}{l}\text { HRT } \\
\text { (days) }\end{array}$ & References \\
\hline $\begin{array}{l}\text { Particulate phosphorus (PP) } \\
\begin{array}{l}\text { Total dissolved phosphorus } \\
\text { (TDP) }\end{array}\end{array}$ & 32.9 & Ke et al. (2012) \\
$\begin{array}{l}\text { Phosphorus } \\
\text { Phosphorus }\end{array}$ & 43 & 10 & $\begin{array}{c}\text { Garcia et al. } \\
(2002)\end{array}$ \\
Total Kjeldahl nitrogen & 41 & 3 & $\begin{array}{c}\text { Garcia et al. } \\
(2002)\end{array}$ \\
Ammonium & 48 & & $\begin{array}{c}\text { Yeh et al. } \\
(2010)\end{array}$ \\
Ammonia-N & 99.5 & 39.5 & $\begin{array}{c}\text { Yeh et al. } \\
(2010) \\
\text { Leite et al. } \\
(2011)\end{array}$ \\
Ammonia-N & 65 & & $\begin{array}{c}\text { Craggs et al. } \\
(2012)\end{array}$ \\
Dissolved reactive & & & $\begin{array}{c}\text { Craggs et al. } \\
\text { phosphorus }\end{array}$ \\
\hline
\end{tabular}

Other treatment processes include a hybrid system (oxidation pond, a two-stage surface wetland system, and one subsurface-flow wetland) for the treatment of total Kjeldahl nitrogen (TKN) and ammonium (Yeh et al. 2010), four 3.09-ha high-rate algal ponds (HRAPs) treating ammonia-N and dissolved reactive phosphorus (Craggs et al. 2012), high-rate pending (HRP) treatment system for nitrogen and phosphorus (Nurdogan and Oswald 1995), and shallow waste ponds for removing ammonia in landfill leachate (Leite et al. 2011). Tsalkatidou et al. (2013) combined eight vertical construction wetlands, three facultative ponds, and aerobic and maturation ponds to treat nutrient constituents such as nitrate- $\mathrm{N}$, ammonia- $\mathrm{N}$, and total phosphorus. Table 4 summarizes the values for the treatment efficiencies for each nutrient.

\section{Heavy metals}

Without proper treatment, heavy metals at high concentrations can significantly impact the environment and human health, causing damage to the colon, kidneys, skin, and nervous, reproductive, and urinary systems, yet the impact of a heavy metal is contingent on the type and concentration (Ogunfowokan et al. 2008). Nevertheless, oxidation ponds impact human health, causing damage to the colon, kidneys, skin, and nervous, reproductive, and urinary systems, yet the impact of a heavy metal is contingent on the type and concentration (Ogunfowokan et al. 2008). Nevertheless, oxidation ponds can be utilized to treat wastewater with heavy metals by reducing its concentration prior to discharge. 
Table 5 Treatment efficiencies of heavy metals in oxidation ponds

\begin{tabular}{|c|c|c|c|}
\hline $\begin{array}{l}\text { Heavy } \\
\text { metal }\end{array}$ & Wastewater & $\begin{array}{l}\text { Treatment } \\
\text { efficiency }(\%)\end{array}$ & References \\
\hline Iron(II) & $\begin{array}{l}\text { Alkaline anthracite } \\
\text { mine waste }\end{array}$ & 99.7 & Kirby et al. (2009) \\
\hline $\begin{array}{l}\text { Cobalt (Co } \\
\text { II) }\end{array}$ & Textile mill & $58-60$ & Mona et al. (2011) \\
\hline \multicolumn{4}{|l|}{$\begin{array}{l}\text { Chromium } \\
(\mathrm{Cr}(\mathrm{VI}))\end{array}$} \\
\hline Iron & Acid mine drainage & 95 & $\begin{array}{l}\text { Burns et al. } \\
\text { (2012) }\end{array}$ \\
\hline Lead(II) & $\begin{array}{l}\text { Industrial } \\
\text { wastewater }\end{array}$ & $85-95$ & $\begin{array}{l}\text { Banerjee and } \\
\text { Sarker (1997) }\end{array}$ \\
\hline Nickel (Ni) & \multirow[t]{5}{*}{ Acid mine drainage } & $37-87$ & \multirow{4}{*}{$\begin{array}{l}\text { Kalin and } \\
\text { Chaves (2003) }\end{array}$} \\
\hline $\begin{array}{l}\text { Aluminum } \\
(\mathrm{Al})\end{array}$ & & $77-98$ & \\
\hline Zinc (Zn) & & $74-82$ & \\
\hline \multirow[t]{2}{*}{ Iron $(\mathrm{Fe})$} & & $75-98$ & \\
\hline & & 98 & Batty et. al. (2008) \\
\hline Chromium & \multirow{3}{*}{$\begin{array}{l}\text { Kraft pulp and } \\
\text { paper mill }\end{array}$} & 41 & Achoka (2002) \\
\hline Copper & & 39 & Achoka (2002) \\
\hline Nickel & & 16 & Achoka (2002) \\
\hline
\end{tabular}

Several studies have been done to examine the result of oxidation ponds in treating heavy metals. Ali et al. (2011) found that the effluent from treating heavy metals enhanced the quality of soil and increased plant growth potential. Other authors have considered the effects of heavy metal removal in oxidation ponds. Table 5 summarizes the treatment efficiency of heavy metals.

\section{Organics}

Organic removal can be accomplished using either anaerobic or aerobic conditions. In aerobic conditions, organic degradation is a two-stage process. During the first stage, bacteria degrade organic matter into carbon dioxide, water, phosphorus, and ammonia in the presence of oxygen. Next, algae in the presence of light use carbon dioxide and water from bacteria to produce oxygen, water, and new algae. The cycle is repeated-oxygen from the second stage is used by the bacteria to restart the first stage of organic degradation. Under anaerobic conditions (commonly known as anaerobic digestion), the process consists of hydrolysis, acidogeneis, acetogenesis, and methanogenesis. In anaerobic digestion, organic matter is degraded into methane, carbon dioxide, and water (Arthur 1983). During these processes, bacteria and algal biomass increase with decreasing organic material.

Various authors report removal of various forms of organics by oxidation ponds-54\% removal of fluorescent organic matter (Musikavong et al. 2007), 64.77 and
$97.75 \%$ of polycyclic biphenyls (PCBs) (Badawy et al. 2010), and $54 \%$ of dissolved organic matter (Musikavong, and Wattanachira 2007). The BOD removal efficiency is dependent on numerous factors and can vary from approximately $81 \%$ (Yeh et al. 2010), $50 \%$ (Craggs et al. 2003), $50.3 \%$ (Meneses et al. 2005), and others (Banerjee and Sarker 1997; Faleschini et al. 2012; Mtethiwa et al. 2008; Sukias et al. 2001; Tanner and Sukias 2003; Abbasi and Abbasi 2010). The BOD removal is not only dependent on the type of oxidation pond, but on other factors such as the environment (Mara and Pearson 1998).

\section{Other applications}

Oxidation pond treatment analysis has been made in other applications. Spongberg et al. (2011) analyzed oxidation pond treatment performance on pharmaceuticals such as doxycyclines, salicylic acid, triclosan, and caffeine. Gomez et al. (2007) observed 90-95\% removal of estrogenicity. Ahmad et al. (2004) measured low concentrations of pesticides such as heptachlor, dieldrin, and $p p$ dichlorodiphenyltrichloroethane from oxidation pond sludge samples. Khan et al. (2010) analyzed the growth of sorghum using treated wastewater from oxidation ponds.

\section{Pathogens}

From a public health perspective, the overall effects of the presence of pathogens must be taken into account. There are several problematic pathogens such as bacteria, protozoa, helminths, and viruses, which can cause various diseases such as cholera, gastroenteritis, typhoid fever, dysentery, and hepatitis (Parker 1970). The World Health Organization (WHO) provides stringent requirements for effluent based on the amount of pathogens present within the system. For example, nematode discharge is limited to $1 \mathrm{egg} / \mathrm{L}$ into the system (Mara and Pearson 1998). Human health impacts of microorganisms such as chironomid eggs (Senderovich et al. 2008) have also been discussed for their potential effects on public health and the environment. WHO discusses additional concerns for bacteriophage species, F-RNA, and somatic coliphages $10^{3}-10^{4}$ plaque-forming units $/ \mathrm{mL}$ (Gino et al. 2007), and somatic coliphage (phiX-174) and F-specific RNA phage (MS2) (Benyahya et al. 1998).

Oxidation ponds are capable of treating pathogens as well. There are several parameters that are necessary for treating bacteria_time and temperature, $\mathrm{pH}$, light intensity, and dissolved concentration (Mara and Pearson 1998). Maiga et al. (2009) found E. coli inactivation to be contingent on sunlight, $\mathrm{pH}$, and dissolved oxygen concentration. In addition, Reinoso and Becares (2008) observe that the prevalence of sunlight reduces Cryptosporidium parvum by $40 \%$. 
Oxidation ponds can also reduce other pathogens such as Campylobacter jejuni, Salmonella enterica, and E. coli (Sinton et al. 2007), reducing salmonella in particular by $96.4 \%$ (Gopo et al. 1997). Oxidation ponds can also remove viruses (NoV), $47 \%$ geogroup I (GI) and $67 \%$ geogroup II (GII) (Da Silva et al. 2008).

Oxidation ponds can eliminate fecal coliform, fecal enterococci, $\mathrm{F}^{+}$coliphage, somatic coliphage, and Ascaris eggs by using the four ponds (Nelson et al. 2004). A treatment system consisting of activated sludge, extended aeration, physical, chemical, and biological treatment (BIOFORE), and oxidation ponds successfully removes pathogens (Jamwal et al. 2009), while a pond and wetland system minimizes bacteria by at least one log (Tanner and Sukias 2003). Overall, oxidation ponds can remove pathogens given that the detention time is between a few days to several weeks (Gloyna 1971).

\section{Algae}

Algae are one of the more perennial driving forces with respect to proper treatment within oxidation ponds and are important because they are capable of taking up phosphates, carbon dioxide $\left(\mathrm{CO}_{2}\right)$, and nitrogen compounds such as ammonia and nitrates, incorporating these constituents into algal biomass production. At the same time, algae supply the oxygen necessary for heterotrophic bacteria to degrade organic material (USEPA 1983). Literature describes that a strong algae presence is determined by nutrients, temperatures, and sunlight. Sunlight is also linked to dissolved oxygen concentration $(\mathrm{mg} / \mathrm{L})$ and can predict photosynthetic activity.

There are various algal species utilized such as $C h$ lamydomonas and Euglena. Nevertheless, algae such as Scenedesmus acutus within high-rate oxidation ponds (HROPs)-sedimentation systems reduce TSS (Garcia et al. 2000), while algae species Chlorella vulgaris and Oscillatoria brevis are also effective in treatment (Tharavathi and Hosetti 2003). In addition, microalgae treat polycyclic aromatic hydrocarbons (PAHs), phenolics, and organic solvents (Munoz and Guieysse 2006). Advanced oxidation systems also use microalgae (Ahmad et al. 2004). Other examples of algae species can include Phacus from the phylum Euglenophyta, Chlamydomonas, and Eudorina, (Chlorophyta); Navicula and Cyclotella (Chrysophyta); and Anabaena (Cyanophyta) (Mara and Pearson 1998).

Yet, there are limitations with algae. One of the biggest known problems is finding algae following discharge from the pond (USEPA 1983). Kaya et al. (2007) found that the algae problem is related to high suspended solids (SS) concentrations. Having observed these issues, the authors find that using a laboratory-scale step feed dual treatment (SFDT) and trickling filter (TF) as an addendum to the oxidation ponds improves chlorophyll- $a$ (Chl- $a$ ) from 89.4 to $97 \%$, as long as the hydraulic loading rate is $2 \mathrm{~m}^{3} /$ $\mathrm{m}^{2}$ day. In this study, the TF alone removes 88 and $95 \%$ Chl- $a$. Besides the SS concentrations, additional problems may include the clogging of the system when improperly discharged (Arthur 1983).

Despite these limitations, algae grown within the pond can be harvested (converted into biomass) for the purpose of creating an alternative fuel source, provided that the influent does not contain heavy metals. As a fuel source, algae have many advantages-high productivity, short growth time, low land requirements, and the formation of lipids capable of being converted into fuels (Pittman et al. 2011). Studies show that lipids have a dry weight range between 10 and $30 \%$, where the values can be contingent on the type of wastewater and its associated concentrations (Pittman et al. 2011; Rawat et al. 2011). Algal harvesting creates biofuels such as gas or oil-based fuels, hydrogen gas (Pittman et al. 2011), ethanol, biogas from methane for electricity (Rawat et al. 2011), and biodiesel, a fuel that is biodegradable, renewable, and low in $\mathrm{CO}_{2}$ emissions (Brennan and Owende 2010). Depending on the species, the amount of gas production will vary. For example, Chlorella vulgaris has a potential methane production between 0.6 and $0.8 \mathrm{~L} / \mathrm{g}$ volatile suspended solids (VSS), while Chlorella pyrenoidosa produces $0.8 \mathrm{~L} / \mathrm{g}$ VSS. Other algae species such as Scenedesmus obliquus ranged from 0.6 to $0.7 \mathrm{~L} / \mathrm{g}$ VSS (Singh and Olsen 2011).

Biofuel formation from algae consists of two major processes - conversion of algae into biomass, followed by the formation of gas based on biochemical and thermochemical processes (Pittman et al. 2011; Rawat et al. 2011). Figure 7 provides a process flow diagram of the algal harvesting process. Conventional algal harvesting

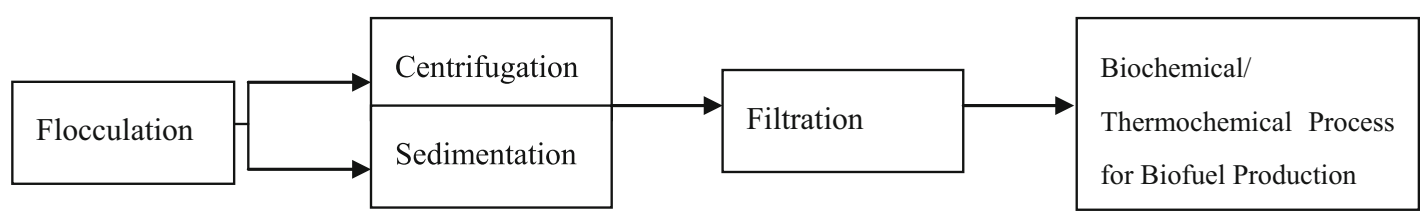

Fig. 7 Conventional process flow diagram of algal harvesting process for biofuel production (adapted from Pittman et al. 2011; Rawat et al. 2011) 
Table 6 Thermochemical processes used in biomass conversion

\begin{tabular}{|c|c|c|}
\hline Process & Description & Requirements \\
\hline Gasification & $\begin{array}{l}\text { Formation of syngas or } \\
\text { combustible gas }\end{array}$ & $\begin{array}{l}\mathrm{CO}_{2}, \mathrm{CH}_{4} \\
\mathrm{H}_{2}\end{array}$ \\
\hline Pyrolysis & $\begin{array}{l}\text { Biomass from charcoal, based on } \\
\text { temperature }\end{array}$ & $\begin{array}{r}\mathrm{O}_{2} / \text { air }(\text { not } \\
\text { required) }\end{array}$ \\
\hline Liquefaction & $\begin{array}{l}\text { Breakdown of biomass by low } \\
\text { temperature and high pressure }\end{array}$ & Catalyst \\
\hline Transesterification & $\begin{array}{l}\text { Conversion of lipids into } \\
\text { biodiesel }\end{array}$ & $\begin{array}{l}\text { Alcohol, } \\
\text { catalyst }\end{array}$ \\
\hline Combustion & $\begin{array}{l}\text { Converts biomass into biofuel at } \\
\text { high temperatures }\end{array}$ & Air \\
\hline
\end{tabular}

Based on the descriptions recorded from Rawat et al. (2011)

begins with flocculation, or the neutralization of the negatively charged algal constituents for the purpose of aggregation (Pittman et al. 2011; Rawat et al. 2011). Flocculation occurs by the use of alum (Pittman et al. 2011) or polymers (Rawat et al. 2011). Following flocculation, biomass is then separated from algal cells and recovered by the use of either centrifugation or gravity sedimentation. An additional biomass recovery procedure consists of biomass attached onto constituents such as alginates in a process known as immobilization (Pittman et al. 2011; Rawat et al. 2011).

Following algal harvesting, the biomass undergoes thermo or biochemical processes, converting biomass into biofuels, where thermochemical processes can include gasification, pyrolysis, liquefaction, and combustion, while anaerobic digestion and fermentation encompass the major biochemical processes (Pittman et al. 2011; Rawat et al. 2011). Table 6 describes some of the major thermochemical processes that have been employed for biomass conversion. Nonetheless, algal harvesting has several limitations.

First, the majority of the algae are unicellular and low in density, making harvesting very expensive (Rawat et al. 2011; Brennan and Owende 2010). Second, several life cycle assessments (LCAs) indicate that various setbacks need to be addressed. An LCA completed by Campbell et al. (2011) found that while biodiesel reduces greenhouse gas emissions when compared with fossil fuel and canolabased biodiesel production of $15 \mathrm{~g} / \mathrm{m}^{2}$ day and $30 \mathrm{~g} /$ $\mathrm{m}^{2}$ day, biodiesel is more expensive than fossil fuel and canola-based fuels (Campbell et al. 2011). Singh and Olsen (2011) concluded that biodiesel production has high electricity costs and water requirements-for every $1 \mathrm{~kg}$ of biodiesel produced, $3726 \mathrm{~kg}$ of freshwater is required. Algal harvesting also requires a supply of nitrogen, usually from chemical fertilizers (Clarens et al. 2010), phosphorus, potassium, and sulfur (Singh and Olsen 2011). Another LCA finds that when comparing algae, corn, canola, and switchgrass as a potential biofuel, algae have the highest energy production, lowest land requirement, and eutrophication potential, but corn and switchgrass reduce greenhouse gases more efficiently (Clarens et al. 2010).

On the other hand, there are ways to resolve these difficulties and continue using algae for biofuel production. For example, if algae are grown within wastewater or saltwater, water requirements are reduced to approximately $400 \mathrm{~kg} / 1 \mathrm{~kg}$ of biodiesel, along with nutrients due to their availability within wastewater (Singh and Olsen 2011; Clarens et al. 2010). Still, future studies need to be conducted to address many of the concerns that have been mentioned in the various life cycle analyses, specifically the costs associated with using algae biomass for the purpose of forming biofuels.

A more recent application is the uptake of phosphorus by algae within waste stabilization ponds. Phosphorus uptake by microalgae is necessary, but only in limited quantities. Nevertheless, there are some instances where the uptake of phosphorus by microalgae is greater than what is required for viability. This process is known as luxury uptake. In luxury uptake, microalgae take available phosphorus from the environment and store unused phosphorus as polyphosphate. The forms of polyphosphate stored are either acid-soluble polyphosphate (ASP) or acidinsoluble polyphosphate (AISP). Stored polyphosphates are used in situations when phosphate concentrations are low.

Luxury uptake has been observed in natural environments. In literature, the authors evaluate luxury uptake on three factors-phosphorus concentration, light intensity, and temperature. Results from the study indicate that the use of phosphorus concentration is contingent on the difference between batch and continuous reactors. Light intensity and temperature affect the rate of polyphosphate accumulation by algae. Full-scale waste stabilization ponds validate the experiments. However, luxury uptake research is still in infant stages. Questions such as determining the effects of mixing and detention time on phosphorus uptake and the optimum ideal phosphorus, bacteria, and algal concentrations still need to be answered (Brown and Shilton 2014).

\section{Greenhouse gas emissions}

Despite many advantages, waste stabilization ponds have been linked with emitting greenhouse gases. There are three recognized greenhouse gases-methane $\left(\mathrm{CH}_{4}\right)$, carbon dioxide $\left(\mathrm{CO}_{2}\right)$, and nitrous oxide $\left(\mathrm{NO}_{\mathrm{x}}\right)$ (HernandezPaniagua et al. 2014; Khatiwada and Silveira 2011). In general, wastewater treatment processes contribute to $5 \%$ of the greenhouse gas production in the world, where anaerobic treatment methods are the most responsible (Cakir and Stenstrom 2005). According to Hernandez- 
Paniagua et al. (2014), stabilization ponds typically emit $85 \mathrm{~g} / \mathrm{m}^{2}$ day of $\mathrm{CO}_{2}$ and $86 \mathrm{~g} / \mathrm{m}^{2}$ day of $\mathrm{CH}_{4}$, with nitrous oxide levels significantly lower. In fact, methane emissions in a waste stabilization pond were reported to be twice as high compared to activated sludge systems (HernandezPaniagua et al. 2014).

At the aerobic layer near the surface of the pond, methane will oxidize to $\mathrm{CO}_{2}$. However, it has been observed that methane emissions are much higher in ponds as compared to carbon dioxide (Silva et al. 2012). This has been attributed to the fact that during photosynthesis algae, use atmospheric carbon dioxide, raising the $\mathrm{pH}$. At higher $\mathrm{pH}$ levels, dissolved carbon dioxide is converted to carbonic acid and bicarbonates (Silva et al. 2012). Algae are also responsible for biologically fixing carbon dioxide and converting atmospheric carbon dioxide into a solid, thereby reducing the emission of $\mathrm{CO}_{2}$ (Shilton et al. 2008). Nevertheless, the release of $\mathrm{CO}_{2}$ into the atmosphere is still dependent upon the $\mathrm{pH}$ value of the system.

While waste stabilization ponds are responsible for a small portion of the world's greenhouse gas emissions (particularly methane), there is an opportunity for the gas, commonly known as biogas, to be recovered and used as a source of energy (Konate et al. 2013). While biogas primarily consists of methane, it is also made up of carbon dioxide, oxygen, and other gases (NIWA 2008). Nevertheless, methane is the main gas targeted when considering biogas recovery. Biogas is formed either during anaerobic digestion of organic compounds or the reduction of carbon dioxide and hydrogen (El-Fadel and Massoud 2001). As a viable energy option, it has been seen as being ideal for electricity generation in a wastewater treatment plant as natural gas, provided that it has undergone several treatment processes (Craggs et al. 2014), or for heat and power (NIWA 2008). If biogas is not recovered for energy, it can be flared off or transitioned into an aerobic pond if a multiple pond system exists (NIWA 2008).

The recovery of biogas is not a novel idea. As a matter of fact, recovery of biogas in pond systems began appearing in peer-reviewed journals within animal waste operations no later than the 1970s (Safley and Westerman 1988). Recently, authors have studied biogas recovery in stabilization ponds from various types of wastewater. For example, Park and Craggs (2007) found a mean areal biogas production of $0.78 \mathrm{~m}^{3} / \mathrm{m}^{2}$ day from piggery wastewater and $0.03 \mathrm{~m}^{3} / \mathrm{m}^{2}$ day from dairy wastewater (Park and Craggs 2007). Konate et al. (2013) recorded a mean areal biogas production of $0.121 \mathrm{~m} / \mathrm{m}^{2}$ day from domestic wastewater in an anaerobic pond. McGrath and Mason (2004) observed biogas production between 0.002 and $0.039 \mathrm{~m}^{3} / \mathrm{m}^{2}$ day in dairy wastewater. Heubeck and Craggs (2010) found an average annual methane production rate of $0.263 \mathrm{~m}^{3} \mathrm{CH}_{4} / \mathrm{kg} \mathrm{VSS}$ added from a piggery pond.
For a pond to be efficient in producing a substantial amount of biogas to be recovered, several parameters must be considered. Two of the most important parameters are the ambient air and pond temperatures. It has been determined that there is a power law relationship between biogas production and ambient temperature. This is expressed in the following equation (McGrath and Mason 2004):

$R=1.241\left(T_{\mathrm{a}}\right)^{1.127}$,

where $R$ is the areal biogas production $\left(\mathrm{L} / \mathrm{m}^{2}\right.$ day) and $T_{\mathrm{a}}$ the ambient air temperature $\left({ }^{\circ} \mathrm{C}\right)$.

With regard to pond temperature, typical biogas production in stabilization ponds occurs in the temperature range between $10^{\circ}$ and $30^{\circ}$ where a linear relationship exists between $10^{\circ}$ and $20^{\circ}$ (McGrath and Mason 2004). Other parameters can include pond geometry (Konate et al. 2013), $\mathrm{pH}$, retention time, treatment method, and microorganism presence (El-Fadel and Massoud 2001). BOD and COD loading rate is also important as the production of methane increases with increase in wastewater strength (El-Fadel and Massoud 2001; Cakir and Stenstrom 2005).

The most efficient way found is to fully or partially cover the pond surface with a material made usually of high-density polyethylene (HDPE) or polypropylene (PP). The pond cover serves as a way to capture the gas generated from anaerobic digestion. Covers are usually designed to extend through the pond's perimeter where it is either placed in a trench or held in place by means of a concrete slab. After the biogas is captured, it is collected by perforated pipes located below the cover. From the pipes, the biogas is removed from the cover by a vacuum (e.g., centrifugal fan) (NIWA 2008). Several authors have recorded the application of covers to capture biogas in municipal wastewater treatment systems. DeGarie et al. (2000) discussed the implementation of a three-layer cover consisting of geomembrane, polyform, and HDPE in Melbourne (Australia). The biogas cover was placed on the anaerobic lagoons in the wastewater treatment plant. Shelef and Azov (2000) constructed a waste stabilization pond system in the Negev desert of Israel. The pond treatment system consisted of anaerobic ponds, stabilization ponds, rock filters, and stabilization reservoirs. The authors included a cover on the anaerobic pond.

There are some points that need to be considered when recovering biogas from a pond. One of the most important is cost. The associated costs for biogas recovery include construction costs of the pond, capital and operation and maintenance costs for gas purification such as gas scrubbing, any capital and operation and maintenance costs to apply biogas for other uses, and the cost for cover design (Craggs 2004). Other potential design considerations include sludge management and the maintenance of a proper organic removal with biogas recovery (DeGarie et al. 
2000). Optimizing the $\mathrm{pH}$, nutrients, temperature, organic loading, and retention time are also important because it will assist in producing an effective biogas system (Kaewmai et al. 2013). These and many other considerations must be addressed when attempting to recover biogas from a pond.

In summary, waste stabilization ponds are capable of producing greenhouse gases, particularly methane. However, applying techniques such as pond covers can mitigate the emission of greenhouse gases and provide a viable source of energy.

\section{Costs}

The cost of an oxidation pond is contingent on the year and the particular country where it is to be built. This is because labor and material costs are not uniform around the world. Nevertheless, there are various analyses available to determine the feasibility of installing oxidation ponds. As with any treatment project, the major costs are capital costs (construction costs) and operation and maintenance (O\&M) costs. Examples of capital costs include construction, administration/legal, land, structures, and architecture/engineering $(\mathrm{A} / \mathrm{E})$ fees, while energy is the primary operation and maintenance $(\mathrm{O} \& \mathrm{M})$ cost. Cost data to build an oxidation pond facility in the USA is presented below.

There are two heavily cited sources for construction cost data in the USA-the Environmental Protection Agency (EPA) and the World Bank. In 1978, the EPA compiled construction costs based on data collected from oxidation pond use in Kansas City/St. Joseph, Missouri. The initial costs of an oxidation pond include 15 different parameters. Results from the EPA study conclude that oxidation ponds have a lower cost per capita as compared to primary and secondary treatment when considering populations between 100 and 100,000. The study also finds that estimated capital costs ranged between $\$ 0.20$ and \$1.00/population equivalent/year (Gloyna 1971). Recently, the EPA published updated construction cost data for the year 2006. In this publication, the EPA states that this data can be calculated for any US city. This is accomplished by multiplying the cost and the ratio of the Engineering News Record Construction Cost (ENR CC) index for a given city by the primary operation and maintenance (O\&M) cost. Cost data to build an oxidation pond facility in the USA is presented below. The ENR CC index is for Kansas City in 2006. The ENR CC indexes are accessible at http://www.enr.com (USEPA 1983). In 1983, the World Bank published data comparing the capital and operation and maintenance costs of oxidation ponds with other natural treatment methods such as aerated lagoons, oxidation ditches, and biological
Table 7 Capital and operation costs for natural wastewater treatment methods (Arthur 1983; Varon and Mara 2004)

\begin{tabular}{lll}
\hline Treatment systems & $\begin{array}{l}\text { Capital costs } \\
\text { (US\$, millions) }\end{array}$ & $\begin{array}{l}\text { Operational costs } \\
\text { (US\$/capita) }\end{array}$ \\
\hline Waste stabilization pond & 5.7 & 0.2 \\
Aerated lagoon system & 7.0 & 1.2 \\
Oxidation ditch system & 4.8 & 1.4 \\
Biological filter & 7.8 & 0.8 \\
\hline
\end{tabular}

filters. The study calculates capital costs by totaling the land, earthworks, structure, and equipment costs (Arthur 1983). Results from this report estimate that the capital costs of an oxidation pond totaled 7.3 million US\$, while annual operation costs were $\$ 50,000 /$ year. Furthermore, the report discovers that oxidation ponds have the lowest capital and operational costs as compared to other natural treatment methods (Arthur 1983; Varon and Mara 2004). Table 7 provides an example of costs between the three natural treatment methods.

On the other hand, the Water Environmental Federation (WEF) published data to approximate the cost of an oxidation pond for a residential area. The WEF conclude that the size of the population appropriates the value of the oxidation pond. For example, the $\$ 7.3$ million dollar estimate would be at the higher end of treatment for a population of about 250,000. Considering that many oxidation ponds would be used for smaller communities, the total costs, including capital and operation and maintenance, can range between $\$ 316,400$ for 20 homes and $\$ 4.7$ million for 200 homes (WEF 2010) or approximately \$2600-\$7600 per home (USEPA 2002).

\section{Modeling}

When evaluating the performance of a waste stabilization pond, it is imperative to consider additional factors that impact the performance of the pond beyond the mere parameters that have been previously discussed. One of the best ways to make the determinations is by using modeling software. Although its popularity began in the mid-1990s, computational fluid dynamics (CFD) has evolved parallel to the advancement of computer technology. CFD models the performance of the pond in removing nutrients, BOD, sedimentation, and pathogens. CFD can vary with meteorological conditions, pond orientation, and design adjustments (Sah et al. 2012). CFD benefits the researcher insomuch as he or she is able to determine how varying the effects of conditions within waste stabilization ponds would affect the performance of removing various constituents. This is beneficial whenever the conditions are unfavorable for sampling (Karteris et al. 2005). 
Various authors discuss the significance of the use of CFD in its ability to analyze treatment performance. Wood et al. (1995) initiated the use of CFD by using two-dimensional computational fluid dynamics (2-D CFD) models for the purpose of designing an optimum treatment performance.

The attempt was to derive conclusions by trying to transfer a three-dimensional entity into two-dimensional space, without the consideration of the depth changes, turbulence-caused mechanical aeration, and the nonisothermal conditions that can potentially exist within a pond under given circumstances. An additional study by Wood et al. (1998) determined that the inlet geometry had a major impact on the water flow, concluding that models are capable of determining water flow effects by varying different parameters. Also Olukanni and Ducoste (2011) determined bacteria removal by using both 2-D CFD and optimization. The authors analyzed baffle adjusted by CFD, while optimization was used to determine the minimal construction costs of waste stabilization ponds.

CFD can incorporate various parameters such as sludge accumulation, temperature, and sunlight. Alvarado et al. (2012) determined that sludge accumulation and settling of sludge within waste stabilization ponds increases as water moves away from the inlet and the velocity decreases. Karteris et al. (2005) created a temperature model within a covered anaerobic pond under unsteady state conditions. Sweeney et al. (2007) analyzed the effects of the presence of sunlight when considering the water quality between the summer and winter months.

Recent investigations into CFD modeling have been conducted to further improve the performance of waste stabilization ponds. Alvarado et al. (2013) deduced the appropriate number of aerators to achieve proper mixing within a waste stabilization pond. The results from the study are further supported by the use of tracer studies completed on a full-scale waste stabilization pond. Hadiyanto et al. (2013) analyzed the length-to-width $(\mathrm{L}: \mathrm{W})$ ratio using dimensions from a currently operating pond in the Netherlands to investigate power consumption, dead zones, and large eddy formation. Also, the authors not only incorporate a discussion on the relationship with velocity and shear stress, but include the effects of shear stress and turbulence on the growth of microorganisms and algae.

Martinez et al. (2014) compared traditional methods of pond design with mathematical software (Matlab) to find a cost-effective facultative pond that can reduce fecal coliform and BOD. The authors examine each method based on the number of baffles and the hydraulic efficiency. Results from the study conclude that the mathematical model can reduce cost by $11 \%$, the area requirement by $18 \%$, and the hydraulic retention time by 19 days.
Lee and Cheong (2014) used numerical modeling to vary the L:W ratio, pond shape, flow rate, and depth under constant pressure and a steady state flow to understand its effects on pond flow characteristics to treat acid mine drainage (AMD). The authors found that the retention time in rectangular ponds decreased with increasing elongation. Pond depth also has an impact on the retention time. An optimum depth for a rectangular pond is $2 \mathrm{~m}$ given a pond area of $500 \mathrm{~m}^{2}$.

As seen within this section, modeling for waste stabilization ponds has been conducted and improved to not only consider specific individual constituents, but also model various phenomena that can occur within the system. Yet, various parameters are highlighted individually within computation models. Currently, no published work has been able to provide a complete profile of wastewater entering the system or through multiple pond systems. With the constant evolution of software, modeling waste stabilization ponds could experience further advancement. Sah et al. (2012) agreed with this sentiment. In addition, the authors recommended that upto-date full-scale data should be available to verify the accuracy of the models (Sah et al. 2012).

Oxidation ponds or waste stabilization ponds are a very effective treatment option not only as tertiary treatment, but also in areas that are not capable of having conventional domestic wastewater treatment or other technologically advanced methods, as seen in Pena et al. (2002) in Columbia. Yet, the design of an oxidation pond is congruent to the location of the pond, as loading rates will vary based on temperature and climate (Mara and Pearson 1998; Gloyna 1971).

To ensure proper treatment, the operator must avoid the possibility of effluent discharge that can contaminate the environment or jeopardize public health. There are many ways that these dangers can be avoided. First, maintain all piping and other treatment unit equipment properly, along with monitoring the conditions within the pond to provide enclosure of treated waste without exposure to the external environment or the formation of residuals. Second, evaluate pathogen presence by taking samples. This will determine if the pond system is having issues. Finally, design the pond system to produce the best efficiency based on the given standards. Computer modeling provides an effective way of confirming the best treatment necessary for the given condition. If the efficiency cannot be met by one pond, another alternative is to create a multiple-staged treatment system of ponds, or include another method of treatment for maximum results.

Computer modeling provides an effective way of confirming the best treatment necessary for the given condition. If the efficiency cannot be met by one pond, another alternative is to create a multiple-staged treatment system of ponds, or include another method of treatment for maximum results. 


\section{Conclusions}

Waste stabilization ponds have demonstrated the capabilities of being a viable treatment technology, specifically in small communities and developing countries because of their inexpensive maintenance and simple design. As the worldwide water crisis increases, wastewater effluent reuse, specifically from waste stabilization ponds in some fashion, will continue to increase (Mara 2012).

Two recommendations will need to be considered for the purpose of expanding this treatment technology. First, reevaluate how the treatment efficiency relates to the corresponding treatment standards for the purpose of effluent reuse. WHO has published guidelines for wastewater reuse in a four-volume publication titled: Guidelines for the safe use of wastewater, excreta and greywater in agriculture and aquaculture (WHO 2006). This document outlines standards that are necessary to ensure that the effluent from the pond is suitable for use in these applications, a very important factor in the current attempt to advocate pond wastewater as a viable alternative. The efforts to implement WHO's guidelines will assure both citizens and governmental agencies that human health and safety is a top priority. Modeling software can be used as a tool that will provide the engineer an opportunity to design a pond that will comply with these standards. Second, retrofit current infrastructure and add stations for fuel production can provide a return on the investment when transitioning waste stabilization ponds for use in larger communities. However, biofuel production will depend on the economic viability of recovery. Despite many technological advances, the main challenge is overcoming the preference of using conventional treatment methods such as activated sludge and trickling filters to comply with treatment standards. Nevertheless, future research addressing the concerns with this section, along with those made throughout the course of this text, may persuade designers and treatment operators to reconsider their stance of minimizing the use of oxidation ponds.

Acknowledgments The authors would like to thank Mr. Jon Sessions, City Manager, and the City of Wellington, TX, for granting permission to take pictures of the city's pond treatment system.

Open Access This article is distributed under the terms of the Creative Commons Attribution 4.0 International License (http://creativecommons.org/licenses/by/4.0/), which permits unrestricted use, distribution, and reproduction in any medium, provided you give appropriate credit to the original author(s) and the source, provide a link to the Creative Commons license, and indicate if changes were made.

\section{References}

Abbas H, Nasr R, Seif H (2006) Study of waste stabilization pond geometry for the wastewater treatment efficiency. Ecol Eng $28: 25-34$
Abbasi T, Abbasi SA (2010) Enhancement in the efficiency of existing oxidation ponds by using aquatic weeds at little or no extra cost - the macrophyte-upgraded oxidation pond (MUOP). Bioremediation J 14:67-80

Achoka JD (2002) The efficiency of oxidation ponds at the kraft pulp and paper mill at Webuye in Kenya. Water Res 36:1203-1212

Ahmad UK, Ujang Z, Woon CH, Indran S, Mian MN (2004) Development of extraction procedures for the analysis of polycyclic aromatic hydrocarbons and organochlorine pesticides in municipal sewage sludge. Water Sci Technol 50:137-144

Ali HM, EL- EM, Hassan FA, EL-Tarawy MA (2011) Usage of sewage effluent in irrigation of some woody tree seedlings. Part 3: Swietenia mahagoni (L.) Jacq. Saudi J Biol Sci 18:201-207

Alvarado A, Sanchez E, Durazno G, Vesvikar M, Nopens I (2012) CFD analysis of sludge accumulation and hydraulic performance of a waste stabilization pond. Water Sci Technol 66:2370-2377

Alvarado A, Vesvikar M, Cisneros JF, Maere T, Goethals P, Nopens I (2013) CFD study to determine the optimal configuration of aerators in a full-scale waste stabilization pond Water Res 47:4528-4537

Amengual-Morro C, Moya Niell G, Martinez-Taberner A (2012) Phytoplankton as bioindicator for waste stabilization ponds. J Environ Manag 95:S71-S76

Arthur JP (1983) Notes on the design and operation of waste stabilization ponds in warm climates of developing countries. [Online] The World Bank, Washington. http://www-wds. worldbank.org/external/default/WDSContentServer/WDSP/IB/ 2002/08/27/000178830_9810190416457/Rendered/PDF/multi Opage.pdf. Accessed 18 Oct 2013

Badawy MI, El-Wahaab RA, Moawad A, Ali MEM (2010) Assessment of the performance of aerated oxidation ponds in the removal of persistent organic pollutants (POPs): a case study. Desalination 251:29-33

Badrot-Nico F, Guinot V, Brissaud F (2010) Taking wind into account in the design of waste stabilisation ponds. Water Sci Technol 61:937-944

Banerjee G, Sarker S (1997) The role of salvinia rotundifolia in scavenging aquatic $\mathrm{Pb}(\mathrm{II})$ pollution: a case study. Bioprocess Eng 17:295-300

Benyahya M, Bohatier J, Laveran H, Senaud J, Ettayebi M (1998) Comparison of elimination of bacteriophages MS2 and phi X-174 during sewage treatment by natural lagooning or activated sludges. A study on laboratory-scale pilot plants. Environ Technol 19:513-519

Bhatnagar A, Bhatnagar M, Chinnasamy S, Das KC (2010) Chlorella minutissima-A promising fuel alga for cultivation in municipal wastewaters. Appl Biochem Biotechnol 161:523-536

Brennan L, Owende P (2010) Biofuels from microalgae-a review of technologies for production, processing, and extractions of biofuels and co-products. Renew. Sust Energ Rev 14:557-577. https://wiki.umn.edu/pub/Biodiesel/WebHome/An_intensive_ continuousnext_term_culture_system_using_tubular_photobio reactors_for_producing_previous_termmicroalgae.pdf. Accessed 20 Aug 2013

Brown N, Shilton A (2014) Luxury uptake of phosphate by microalgae in waste stabilization ponds: current understanding and future direction. Rev Environ Sci Biotechnol 13:321-328

Burns AS, Pugh CW, Segid YT, Behum PT, Lefticariu L, Bender KS (2012) Performance and microbial community dynamics of a sulfate-reducing bioreactor treating coal generated acid mine drainage. Biodegradation 23:415-429

Cakir FY, Stenstrom MK (2005) Greenhouse gas production: a comparison between aerobic and anaerobic wastewater treatment technology. Water Res 39:4197-4203

Campbell PK, Beer T, Batten D (2011) Life cycle assessment of biodiesel production from microalgae in ponds. Bioresour Technol 102:50-56

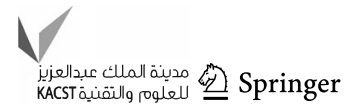


Cinara Columbia (2004). Waste stabilization ponds for wastewater treatment: FAQ sheet on waste stabilization ponds. http://www. irc.nl/page/8237. Accessed 10 May 2013

Clarens AF, Resurreccion EP, White MA, Colosi LM (2010) Environmental life cycle comparison of algae to other bioenergy feedstocks. Environ Sci Technol 44:1813-1819

Cooper RC (1968) Industrial waste oxidation ponds. SW Water Works J 5:21-26

Craggs R (2004) (n.d.) Potential for biogas recovery from anaerobic ponds in New Zealand. http://www.bioenergy.org.nz/documents/ Christchurch\%20Workshop/7_Potential\%20for\%20biogas\% 20recovery\%20from\%20anaerobic\%20ponds\%20in\%20NZ.pdf. Accessed 6 Jan 2015

Craggs RJ, Davies-Colley RJ, Tanner CC, Suklas JP (2003) Advanced pond system: performance with high rate ponds of different depths and areas. Water Sci Technol 48:259-267

Craggs R, Sukias J, Tanner C, Davies-Colley R (2004) Advanced pond system for dairy-farm effluent treatment. NZ J Agric Res 47:449-460

Craggs R, Sutherland D, Campbell H (2012) Hectare-scale demonstration of high rate algal ponds for enhanced wastewater treatment and biofuel production. J Appl Phycol 24:329-337

Craggs R, Park J, Heubeck S, Sutherland D (2014) High rate algal pond systems for low-energy wastewater treatment, nutrient recovery and energy production. NZ J Bot 52:60-73

Crites RW, Middlebrooks EJ, Reed SC (2006) Natural wastewater treatment systems CRC Press, Boca Raton. http://books.google. com/books?id=X5uuikcVyfEC\&pg=PA193\&dq=Natural + Waste water+Treatment + Completely + Mixed $\&$ hl $=$ en\&sa $=X \&$ ei $=N v 1 f$ Utv7KoPZ2AWk1ICQDA\&ved=0CEkQ6AEwAQ\#v=onepage $\& q=$ Natural $\% 20$ Wastewater $\% 20$ Treatment $\% 20$ Completely $\% 20$ Mixed\&f=false. Accessed 17 Oct 2013

Curtis T, Mara DD, Dixo N, Silva SA (1994) Light penetration in waste stabilization ponds. Water Res 28:1031-1038

Da Silva AK, Le Guyader FS, Le Saux J, Pommepuy M, Montgomery MA, Elimelech M (2008) Norovirus removal and particle association in a waste stabilization pond. Environ Sci Technol 42:9151-9157

Daviescolley RJ, Hickey CW, Quinn JM (1995) Organic-matter, nutrients, and optical characteristics of sewage lagoon effluents. NZ J Mar Freshw Res 29:235-250

Davis ML, Cornwell DA (2008) Introduction to environmental engineering, 4th edn. McGraw-Hill, New York

DeGarie C, Crapper T, Howe B, Burke B, McCarthy P (2000) Floating geomembrane covers for odour control and biogas collection and utilization in municipal lagoons. Water Sci Technol 42:291-298

Eckenfelder WW (1961) Biological waste treatment. Pergamon Press, London

El-Fadel M, Massoud M (2001) Methane emissions from wastewater management. Environ Poll 114:117-185

Faleschini M, Esteves JL, Valero MAC (2012) The effects of hydraulic and organic loadings on the performance of a full-scale facultative pond in a temperate climate region (Argentine Patagonia). Water Air Soil Poll 223:2483-2493

Finney BA, Middlebrooks EJ (1980) Facultative waste stabilization design. J Water Poll Control Fed 134-147. http://www.jstor.org/ stable/25040557. Accessed 15 Oct 2013

Fyfe J, Smalley J, Hagare D, Sivakumar M (2007) Physical and hydrodynamic characteristics of a dairy shed waste stabilisation pond system. Water Sci Technol 55:11-20

Garcia J, Hernandez-Marine M, Mujeriego R (2000) Influence of phytoplankton composition on biomass removal from high-rate oxidation lagoons by means of sedimentation and spontaneous flocculation. Water Environ Res 72:230-237
Garcia J, Hernandez-Marine M, Mujeriego R (2002) Analysis of key variables controlling phosphorus removal in high rate oxidation ponds provided with clarifiers. Water SA 28:55-62

Gino E, Starosvetsky J, Armon R (2007) Bacteriophage ecology in a small community sewer system related to their indicative role in sewage pollution of drinking water. Environ Microbiol 9:2407-2416

Gloyna EF (1971) Waste stabilization ponds. World Health Organization, Geneva. http://apps.who.int/iris/bitstream/10665/41786/ 1/WHO_MONO_60_\%28part1\%29.pdf. Accessed 18 Oct 2013

Gomez E, Wang X, Dagnino S, Leclercq M, Escande A, Casellas C, Picot B, Fenet H (2007) Fate of endocrine disrupters in waste stabilization pond systems. Water Sci Technol 55:157-163

Google Maps (2014) [City of Wellington, Wellington, Texas] [Google Earth]. https://www.google.com/maps/@34.8454567, $-100.2300974,681 \mathrm{~m} / \mathrm{data}=! 3 \mathrm{~m} 1 ! 1 \mathrm{e} 3$

Gopo J, Setoaba M, Lesufi W, Sibara M (1997) Incidence of Salmonella spp. in sewage and semi-urban waste water treated by pond oxidation method at the University of the North. Water SA 23:333-337

Gumisiriza R, Mshandete AM, Rubindamayugi MST, Kansiime F, Kivaisi AK (2009) Enhancement of anaerobic digestion of Nile perch fish processing wastewater. Afr J Biotechnol 8:328-333

GvR Marais (1966) New factors in the design, operation and performance of waste-stabilization ponds. Bull World Health Organ 34:737

Hadiyanto H, Elmore S, Van Gerven T, Stankiewicz A (2013) Hydrodynamic evaluations in high rate algae pond (HRAP) design. Chem Eng J 217:231-239

Halpern M, Shaked T, Schumann P (2009) Brachymonas chironomi sp nov., isolated from a chironomid egg mass, and emended description of the genus Brachymonas. Int J Syst Evol Microbiol 59:3025-3029

Hamdan R, Mara DD (2011) The effect of aerated rock filter geometry on the rate of nitrogen removal from facultative pond effluents. Water Sci Technol 63:841-844

Hamilton DW, Fathepure B, Fulhage CD, Clarkson W, Lalman J (2006) Treatment lagoons for animal agriculture. Animal agriculture and the environment: National Center for Manure and Animal Waste Management White Papers 547-574. http:// osuwastemanage.bae.okstate.edu/articles-1/lagoonwp.pdf. Accessed 17 Oct 2013

Hernandez-Paniagua IY, Ramirez-Vargas R, Ramos-Gomez MS, Dendooven L, Avelar-Gonzalez FJ, Thalasso F (2014) Greenhouse gas emissions from stabilization ponds in subtropical climates. Environ Technol 35:727-734

Heubeck S, Craggs R (2010) Biogas recovery from a temperate climate covered anaerobic pond. Water Sci Technol 61:1019-1026

Hosetti B, Frost S (1995) A review of the sustainable value of effluents and sludges from wastewater stabilization ponds. Ecol Eng 5:421-431

Hosetti B, Frost S (1998) A review of the control of biological waste treatment in stabilization ponds. Crit Rev Environ Sci Technol 28:193-218

Jamwal P, Mittal AK, Mouchel J (2009) Efficiency evaluation of sewage treatment plants with different technologies in Delhi (India). Environ Monit Assess 153:293-305

Joint Departments of the Army, the Navy, and the Air Force (1988) Chapter 14: Wastewater treatment ponds. In: Domestic wastewater treatment. Army TM 5-814-3 and Air Force AFM 88-11, vol. 3. TM 5-814-3/AFM 88-11, Volume III, Washington DC http://www.discountpdh.com/course/domestic/Domestic\%20Waste water\%20Treatment\%20chap14.pdf. Accessed 18 Oct 2013

Kaewmai R, H-Kittikun A, Suksaroj C, Musikavong C (2013) Alternative technologies for the reduction of greenhouse gas 
emissions from palm oil mills in Thailand. J Environ Sci Technol 47:12417-12425

Kalin M, Chaves W (2003) Acid reduction using microbiology: treating AMD effluent emerging from an abandoned mine portal. Hydrometallurgy 71:217-225

Karteris A, Papadopoulos A, Balafoutas G (2005) Modeling the temperature pattern of a covered anaerobic pond with computational fluid dynamics. Water Air Soil Poll 162:107-125

Kaya D, Dilek FB, Goekcay CF (2007) Reuse of lagoon effluents in agriculture by post-treatment in a step feed dual treatment process. Desalination 215:29-36

Kayombo S, Mbwette TSA, Katima JHY, Ladegaard N, Jorgensen SE (2010) Waste stabilization ponds and constructed wetland design manual. UNEP International Environmental Technology Center. http://www.unep.or.jp/Ietc/Publications/Water_Sanitation/ponds_ and_wetlands/Design_Manual.pdf. Accessed 18 Oct 2013

Ke F, Li WC, Li HY, Xiong F, Zhao AN (2012) Advanced phosphorus removal for secondary effluent using a natural treatment system. Water Sci Technol 65:1412-1419

Khan MA, Shaukat SS, Hany O, Jabeen S (2010) Irrigation of sorghum crop with waste stabilization pond effluent: growth and yield responses. Pak J Bot 42:1665-1674

Khatiwada D, Silveira S (2011) Greenhouse gas balances of molasses based ethanol in Nepal. J Clean Prod 19:1471-1485

Kirby CS, Dennis A, Kahler A (2009) Aeration to degas $\mathrm{CO}_{2}$, increase $\mathrm{pH}$, and increase iron oxidation rates for efficient treatment of net alkaline mine drainage. Appl Geochem 24:1175-1184

Konate Y, Maiga AH, Casellas C, Picot B (2013) Biogas production from an anaerobic pond treating domestic wastewater in Burkina Faso. Desalin Water Treat 51:2445-2452

Lado M, Ben-Hur M (2010) Effects of irrigation with different effluents on saturated hydraulic conductivity of arid and semiarid soils. Soil Sci Soc Am J 74:23-32

Lee DK, Cheong YW (2014) A numerical flow analysis using the concept of inflow age for oxidation pond design. J Environ Manag 133:388-396

Leite VD, Pearson HW, de Sousa JT, Lopes WS, de Luna MLD (2011) The removal of ammonia from sanitary landfill leachate using a series of shallow waste stabilization ponds. Water Sci Technol 63:666-670

Batty L, Hooley L, Younger P (2008) Iron and manganese removal in wetland treatment systems: rates, processes and implications for management. Sci Total Environ 394:1-8

Maiga Y, Wethe J, Denyigba K, Ouattara AS (2009) The impact of pond depth and environmental conditions on sunlight inactivation of Escherichia coli and enterococci in wastewater in a warm climate. Can J Microbiol 55:1364-1374

Malina JF Jr, Rios RA (1976) Anaerobic ponds. In: Gloyna EF, Malina JF Jr, Davis EM (eds) Ponds as a wastewater alternative, water resources symposium, No. 9, University of Texas Press, Austin, TX

Mara D (2012) Waste stabilization ponds: past, present and future. Desalination Water Treat 4:85-88. http://www.tandfonline.com. databases.wtamu.edu:2048/doi/pdf/10.5004/dwt.2009.359. Accessed 3 Nov 2013

Mara D, Pearson H (1998) Design manual for waste stabilization ponds in Mediterranean countries [Online] Lagoon Technology International Ltd, Leeds. http://www.efm.leeds.ac.uk/CIVE/ Sewerage/articles/medall/medall.pdf. Accessed 18 Oct 2013

Mara DD, Mills SW, Pearson HW, Alabaster GP (1992) Waste stabilization ponds-a viable alternative for small community treatment systems. J Inst Water Environ Manag 6:72-78

Martinez FC, Cansino AT, Garcia MAA, Kalashnikov V, Rojas RL (2014) Mathematical analysis for the optimization of a design in a facultative pond: indicator organism and organic matter. Math Probl Eng 1-12

McGrath RJ, Mason IG (2004) An observational method for the assessment of biogas production from an anaerobic waste stabilisation pond treating farm dairy wastewater. Biosyst Eng $87: 471-478$

Meneses CGR, Saraiva LB, Mello HND, de Melo JLS, Pearson HW (2005) Variations in BOD, algal biomass and organic matter biodegradation constants in a wind-mixed tropical facultative waste stabilization pond. Water Sci Technol 51:183-190

Mona S, Kaushik A, Kaushik CP (2011) Hydrogen production and metal-dye bioremoval by a Nostoc linckia strain isolated from textile mill oxidation pond. Bioresour Technol 102:3200-3205

Mtethiwa AH, Munyenyembe A, Jere W, Nyali E (2008) Efficiency of oxidation ponds in wastewater treatment. Int $\mathbf{J}$ Environ Res 2:149-152

Mungraya AK, Kumar P (2008) Occurrence of anionic surfactants in treated sewage: risk assessment to aquatic environment. J Hazard Mater 160:362-370

Munoz R, Guieysse B (2006) Algal-bacterial processes for the treatment of hazardous contaminants: a review. Water Res 40:2799-2815

Musikavong C, Wattanachira S (2007) Reduction of dissolved organic matter in terms of DOC, UV-254, SUVA and THMFP in industrial estate wastewater treated by stabilization ponds. Environ Monit Assess 134:489-497

Musikavong C, Wattanachira S, Nakajima F, Furumai H (2007) Three dimensional fluorescent spectroscopy analysis for the evaluation of organic matter removal from industrial estate wastewater by stabilization ponds. Water Sci Technol 55:201-210

National Institute of Water and Atmospheric Research Ltd (2008) Covered anaerobic ponds for anaerobic digestion and biogas capture piggeries [Online] NIWA Information Series No. 32. Available at http://www.biogas.org.nz/Publications/WhosWho/ biogas-pond-booklet.pdf. Accessed 30 Dec 2014

Nelson KL, Cisneros BJ, Tchobanoglous G, Darby JL (2004) Sludge accumulation, characteristics and pathogen inactivation in four primary waste stabilization ponds in central Mexico. Water Res 38:111-127

Nurdogan Y, Oswald W (1995) Enhanced nutrient removal in highrate ponds. Water Sci Technol 31:33-43

Ogunfowokan AO, Adenuga AA, Torto N, Okoh EK (2008) Heavy metals pollution in a sewage treatment oxidation pond and the receiving stream of the Obafemi Awolowo University, Ile Ife, Nigeria. Enivron Monit Assess 143:25-41

Olaniran AO, Babaloa GO, Okoh AI (2001) Aerobic dehalogenation potentials of four bacterial species isolated from soil and sewage sludge. Chemosphere 45:45-50

Olukanni DO, Ducoste JJ (2011) Optimization of waste stabilization pond design for developing nations using computational fluid dynamics. Ecol Eng 37:1878-1888

Oswald WJ (1968) Advances in anaerobic pond systems design. In: Gloyna EF, Eckenfelder WW Jr (eds) Advances in water quality improvement. University of Texas Press, Austin

Oswald WJ, Golueke CG, Tyler RW (1967) Integrated pond systems for subdivisions. J Water Pollut Control Fed 39:1289-1304

Park J, Craggs R (2007) Biogas production from anaerobic waste stabilisation ponds treating dairy and piggery wastewater in New Zealand. Water Sci Technol 55:257-264

Parker CD (1970) Experiences with anaerobic lagoons in Australia. In: Proceedings of the second international symposium for waste treatment lagoons, Kansas City

Parker CD, Jones HL, Greene NC (1959) Performance of large sewage lagoons at Melbourne, Australia. Sewage Ind Wastes 31:133 
Pearson H, Mara D, Arridge H (1995) The influence of pond geometry and configuration on facultative and maturation waste stabilization pond performance and efficiency. Water Sci Technol 31:129-139

Peña MR, Mara DD (2003) High-rate anaerobic pond concept for domestic wastewater treatment: results from pilot scale experience. In: Water and environmental management series (WEMS). IWA Publishing, London. http://www.bvsde.paho.org/bvsacd/ agua2003/pilot.pdf. Accessed 18 Oct 2013

Pena M, Madera C, Mara D (2002) Feasibility of waste stabilization pond technology for small municipalities in Colombia. Water Sci Technol 45:1-8

Pittman JK, Dean AP, Osundeko O (2011) The potential of sustainable algal biofuel production using wastewater resources. Bioresour Technol 102:17-25

Quiroga FJ (2011) Waste stabilization ponds for waste water treatment, anaerobic pond. http://home.eng.iastate.edu/ $\sim$ tge/ ce421-521/Fernando\%20J.\%20Trevino\%20Quiroga.pdf. Accessed 9 May 2013

Rawat I, Kumar RR, Mutanda T, Bux F (2011) Dual role of microalgae: phycoremediation of domestic wastewater and biomass production for sustainable biofuels production. Appl Energy 88:3411-3424

Reinoso R, Becares E (2008) Environmental inactivation of Cryptosporidium parvum oocysts in waste stabilization ponds. Microb Ecol 56:585-592

Safley LM Jr, Westerman PW (1988) Biogas production from anaerobic lagoons. Biol Waste 23:181-193

Sah L, Rousseau DPL, Hooijmans CM (2012) Numerical modelling of waste stabilization ponds: where do we stand? Water Air Soil Poll 223:3155-3171

Senderovich Y, Gershtein Y, Halewa E, Halpern M(2008) Vibrio cholerae and aeromonas: do they share a mutual host? ISME J 2:276-283

Shelef G, Azov Y (2000) Meeting stringent environmental and reuse requirements with an integrated pond system for the twenty-first century. Water Sci Technol 42:299-305

Shilton AN, Mara DD, Craggs R, Powell N (2008) Solar-powered aeration and disinfection, anaerobic co-digestion, biological $\mathrm{CO}_{2}$ scrubbing and biofuel production: the energy and carbon management opportunities of waste stabilisation ponds. Water Sci Technol 58:253-258

Shpiner R, Vathi S, Stuckey DC (2007) Treatment of oilfield produced water by waste stabilization ponds. Water Sci Technol 55:265-271

Shuval H, Adin A, Fattal B, Rawitz E, Yekutiel P (1986) Integrated resource recovery-wastewater irrigation in developing countries-health effects and technical solutions [Online] World Bank Technical Paper Number 51. The World Bank, Washington DC. http://www-wds.worldbank.org/external/default/WDSCont entServer/WDSP/IB/1999/09/17/00178830_98101904164938/ Rendered/PDF/multi_page.pdf. Accessed 4 Nov 2013

Silva JP, Ruiz JL, Pena MR, Lubberding H, Gijzen H (2012) Influence of photoperiod on carbon dioxide and methane emissions from two pilot-scale stabilization ponds. Water Sci Technol 66:1930-1940

Singh A, Olsen SI (2011) A critical review of biochemical conversion, sustainability and life cycle assessment of algal biofuels. Appl Energy 88:3548-3555. http://www.researchgate. net/publication/230238121_A_viable_technology_to_generate_ thirdgeneration_biofuel/file/79e415033319adeb75.pdf. Accessed 20 Aug 2013

Sinton L, Hall C, Braithwaite R (2007) Sunlight inactivation of Campylobacter jejuni and Salmonella enterica, compared with Escherichia coli, in seawater and river water. J Water Health 5:357-365
Spongberg AL, Witter JD, Acuna J, Vargas J, Murillo M, Umana G, Gomez E, Perez G (2011) Reconnaissance of selected PPCP compounds in Costa Rican surface waters. Water Res 45:6709-6717

Sukias JPS, Craggs RJ (2011) Digestion of wastewater pond microalgae and potential inhibition by alum and ammoniacalN. Water Sci Technol 63:835-840

Sukias JPS, Tanner CC, Davies-Colley RJ, Nagels JW, Wolters R (2001) Algal abundance, organic matter, and physico-chemical characteristics of dairy farm facultative ponds: implications for treatment performance. NZ J Agric Res 44:279-296

Sweeney DG, Nixon JB, Cromar NJ, Fallowfield HJ (2007) Temporal and spatial variation of physical, biological, and chemical parameters in a large waste stabilisation pond, and the implications for WSP modelling. Water Sci Technol 55:1-9

Tanner CC, Sukias JPS (2003) Linking pond and wetland treatment: performance of domestic and farm systems in New Zealand. Water Sci Technol 48:331-339

Tharavathi N, Hosetti B (2003) Biodiversity of algae and protozoa in a natural waste stabilization pond: a field study. J Environ Biol 24:193-199

Thirumurthi D (1974) Design criteria for waste stabilization ponds. J Water Poll Control Fed 2094-2106. http://www.jstor.org/ stable/25038241. Accessed 15 Oct 2013

Tsalkatidou M, Gratziou M, Kotsovinos N (2013) Septage treatment using a combined waste stabilization ponds-vertical flow constructed wetland system. Desalin Water Treat 51:3011-3017

United States Environmental Protection Agency (1983) Design manual: municipal waste stabilization ponds. EPA-625-1-830115. Office of Water, Cincinnati. http://nepis.epa.gov/Exe/Zy NET.exe/300044QA.TXT?ZyActionD=ZyDocument\&Client $=$ EPA\&Index $=1981+$ Thru $+1985 \&$ Docs $=\&$ Query $=\&$ Time $=\&$ End Time $=\&$ SearchMethod $=1 \&$ TocRestrict $=n \&$ Toc $=\&$ TocEntry $=$ $\&$ QField $=\& Q$ FieldYear $=\&$ QFieldMonth $=\& Q$ FieldDay $=\&$ IntQ FieldOp $=0 \&$ ExtQFieldOp $=0 \& X m l Q u e r y=\&$ File $=D \% 3$ Alzyfiles Index\%20Datal81 thru85\Txt $100000001 \backslash 300044 Q A . t x t \&$ User= ANONYMOUS\&Password=anonymous\&SortMethod=hl-\& MaximumDocuments $=1 \&$ FuzzyDegree $=0 \&$ ImageQuality $=r 75 \mathrm{~g} 8 /$ r75g8/x150y 150g 16/i425\&Display=plf\&DefSeekPage $=x \&$ Search Back $=$ ZyActionL \&Back=ZyActionS $\&$ BackDesc $=$ Results $\% 20$ page $\&$ MaximumPages $=1 \& Z y$ Entry $=1 \&$ SeekPage $=x \& Z y P U R L$. Accessed 18 Oct 2013

United States Environmental Protection Agency (2002) Onsite wastewater treatment systems Manual. EPA- 625-R-008. Office of Water, Washington DC. http://water.epa.gov/aboutow/owm/ upload/2004_07_07_septics_septic_2002_osdm_all.pdf. Accessed 16 Apr 2015

United States Environmental Protection Agency (2011) Principles of design and operations of wastewater treatment pond systems for plant operators, engineers, and managers. EPA 600-R-11-088. Office of Research and Development, Cincinnati. http://www. epa.gov/ordntrnt/ORD/NRMRL/lrpcd/projects/ponds.htm. Accessed 18 Oct 2013

Veeresh M, Veeresh AV, Huddar BD, Hosetti BB (2010) Dynamics of industrial waste stabilization pond treatment process. Environ Monit Assess 169:55-65

Varon MP, Mara D (2004) Waste stablization ponds. IRC International Water and Sanitation Centre, Leeds, UK. http:// www.bvsde.paho.org/bvsacd/cd27/ponds.pdf. Accessed 16 Apr 2015

Water Environmental Federation (2010) "Fact sheet T5: performance and cost of decentralized unit processes treatment series: lagoons". Water Environmental Federation, Alexandria. http:// www.werf.org/c/DecentralizedCost/T5_Lagoons.aspx. Accessed 18 Oct 2013 
Wood M, Greenfield P, Howes T, Johns M, Keller J (1995) Computational fluid dynamic modeling of waste-water ponds to improve design. Water Sci Technol 31:111-118

Wood M, Howes T, Keller J, Johns M (1998) Two dimensional computational fluid dynamic models for waste stabilisation ponds. Water Res 32:958-963

World Health Organization (2006) Guidelines for the safe use of wastewater, excreta and greywater. http://www.who.int/water sanitation_health/wastewater/gsuww/en/index.html. Accessed 3 Nov 2013

Yeh TY, Pan CT, Ke TY, Kuo TW (2010) Organic matter and nitrogen removal within field-scale constructed wetlands: reduction performance and microbial identification studies. Water Environ Res 82:27-33 